\title{
Illuminating the Carolingian era: new discoveries as a result of scientific analyses
}

\author{
Charlotte Denoël ${ }^{1}$, Patricia Roger Puyo ${ }^{2^{*}} \mathbb{D}$, Anne-Marie Brunet ${ }^{3}$ and Nathalie Poulain Siloe ${ }^{4}$
}

\begin{abstract}
Comparing information from the ancient texts about the illumination of the manuscripts to the analysis of the components used to create colour in illuminations sheds interesting light. Our research team studied several manuscripts from the Carolingian era issued from different sources including: the Gospels of St Riquier kept in the library of Abbeville (ms. 4), two Theodulphe's Bibles, (Orléans-Fleury, BnF lat.11937 and BnF lat.9380), the Godescalc Evangelistary (BnF NAL 1203), the Gospels of St Denis (BnF lat.9387) and the Gospels of St Médard de Soissons (BnF lat.8850), the last three from the court of Charlemagne, and all preserved at the French National Library. These most luxurious manuscripts were written and illuminated between the late eighth century and the first quarter of the ninth century. Through non-destructive portable visual and spectrometric analysis, our research team was able to identify the palette of materials used in scripts and illuminations and especially highlighted the amazing use of Egyptian blue in a very specific part of the illumination in the Godescalc Evangelistary. Our team also found that some substitutes including folium had been used instead of Tyrian purple for the decoration and to dye the parchment. These manuscripts, produced at the initiative of various patrons during Charlemagne's reign, reveal in the light of the material analysis and the reconstitutions' experiments by professional illuminators their differences and, beyond, the artistic diversity of this very particular period called the Carolingian Renaissance.
\end{abstract}

\section{Introduction}

Under the council of his two advisors Alcuin and Theodulph, Charlemagne implemented new policies that increased manuscripts production. His goals were to salvage classical written documents and to copy texts pertaining to liturgy and education. From there, these policies also aimed to create new liturgical texts such as the gospels [1]. They were implemented in Frankish kingdoms' scriptoria, such as Fleury, Soissons and SaintMartin de Tours. But, beyond the simple text, the school of Charlemagne's court produced luxurious illuminated manuscripts, elevating his reign to an artistic golden age.

We examined this production, especially six manuscripts created in West Francia between the end of the eighth century and the first quarter of the ninth century. The corpus includes works from diverse provenances, currently housed at libraries in Paris and Abbeville,

\footnotetext{
*Correspondence: patricia.roger@cnrs-orleans.fr

${ }^{2}$ CNRS, UMR5060, IRAMAT Centre Ernest-Babelon-Université d'Orléans,

Rue de la Ferollerie, 45100 Orléans, France

Full list of author information is available at the end of the article
}

France. Two Theodulph's Bibles: BnF lat.11937 (OrléansFleury, early 9th c.), and BnF lat.9380 (Orléans-Fleury, 801-818), St Riquier's Gospels: (Abbeville, BM, ms004, before 800), St Denis's Gospels: BnF lat.9387 (end of the 8th c.), the Godescalc Evangelistary: BnF NAL 1203 (781-783) and Saint-Médard de Soissons's Gospels: BnF lat. 8850 (c. 800) [2]. They were written in silver and gold ink, and, for some, on entirely purple parchment. We have analyzed the materials the artists used to produce these texts and embellishments.

\section{Research background \\ The color purple's symbolic meanings}

Antique purple has been used in Tyre since 1200 BCE to dye clothing, and it is the most prestigious natural dye known to the classical world. It is mentioned in many ancient texts, such as a letter from Amenhotep III, as the most famous dye in antiquity. It is also called royal purple [3]. The name "Tyre Purple" refers to Murex and Purpura seashells collected on the Mediterranean seashores. The extract is composed of dark red-purple dyes, "The color
Springer Open

(c) The Author(s) 2018. This article is distributed under the terms of the Creative Commons Attribution 4.0 International License (http://creativecommons.org/licenses/by/4.0/), which permits unrestricted use, distribution, and reproduction in any medium, provided you give appropriate credit to the original author(s) and the source, provide a link to the Creative Commons license, and indicate if changes were made. The Creative Commons Public Domain Dedication waiver (http://creativecommons.org/ publicdomain/zero/1.0/) applies to the data made available in this article, unless otherwise stated. 
of coagulated blood, according to Vitruvius" [4], from Bromos-Indigo [5]. The names of the Bolinus brandaris and Thaïs haemastona, or a combination of both are mentioned in the ancient text [6]: these mollusks' hypobranchial glands feature the chemicals that turn into the famous color once in contact with air and light. Pliny the Elder mentions this process:

The purple have in the middle of the throat this juice so sought for the dye of materials. It is a very small quantity of liquid contained in a white vein... We try hard to take them living beings, because they reject this liqueur by dying. In the biggest, he is extracted having removed the shell; as the little they are crushed living beings... what makes her to them soak [7].

The use of purple dye on antique clothing has been largely researched, for instance by Guilia Motteran in her study of purple gospels in the Late antique period $[8,9]$. The dye would have been used as a paint by fixating it to argil, as a red lacquer; this would be the Purpurissum Pliny mentioned [4], and that was later identified on paintings found at Pompei. In the Roman Republic, purple was the colour of the toga worn by senators and victorious generals. During the Imperial era, it becomes the official colour strictly reserved to the emperors, and as such, its use is entangled with the display of imperial power. In the first century, Caligula introduces the adoratio purpurae, a practice that Diocletian brings to its apogee with the complex ritual of "kissing the purple." Under Nero, anyone but the Emperor wearing purple clothing or even buying purple dye could be sentenced to death [10]. Starting with Commodus (161-192), several emperors then bear the title of Porphyrogennetos, meaning "born in purple," a title that endures during the Byzantine Empire. According to Pliny the Elder, the difficulties to extract the dye and its exorbitant price justify its status as a precious material [11]. It also explains many attempts to imitate or falsify this material [12].

In Biblical texts, purple also has symbolic meanings: it is mentioned several times in the Old and New Testament, as the sign of both human and divine sovereignty. Daniel received a purple garment and a gold necklace as a sign of his new condition. ${ }^{1}$ According to Mark $^{2}$ and John, ${ }^{3}$ Christ is clothed in a purple robe for his crucifixion. Purple then becomes the symbol of Christ's sacrifice, representing the blood Christ shed to redeem humanity. In the Christian church that forms in the first centuries
$\mathrm{AD}$, this double meaning of purple-both tied to the royalty and to the sacrifice-is materialized in dalmatics embellished with two purple stripes. This garment is then worn by the clergy on all hierarchical levels, despite saint Augustine and saint-Jerome's protests against this luxurious piece of clothing that moves away from the simplicity of the first Christians. Using purple in liturgical garments is then maintained in the East and in the West, as literary sources and descriptions of churches' treasures often mention purple clothing, a color the documents usually tie to blood or to the martyrs $[10,13,14]$. Also, Raban Maur writes on associating purple to the blood of Christ in De universo ${ }^{4}$ and De laudibus sanctae crucis. ${ }^{5}$ This type of ostentatious display often raised harsh criticism, as is suggested by Nokter of Saint Gall writing against a bishop wearing imperial purple: "Sedebat autem ipse mollissimis plumis preciosissimo serico vestitis exstructus, imperatoria purpura indutus, ita ut nihil illi nisi sceptrum illud et nomen regium deesset" [15].

The recognition of Christianity as state religion under Emperor Constantine enhances the indexical value of purple: it remains the imperial colour par excellence, in continuity with pagan Rome, but it also commemorates the blood shed by Christ and all the martyrs of the faith.

Purple was first reserved to clothing and fabric, but starting during Constantine's reign, its use reaches imperial documents, which need to be signed with purple ink.

The use of purple ink in written documents increases during Late Antiquity to produce entire Gospel books, in both Greek Orient and Latin Occident. Purple has been identified in the Codex Rossanensis, Rossano Diocesan Museum, and in the Codex Argentus, Upsala University Library [5]. Using the most precious materials to make Gospels books is easily explained: they are the representation of the Revelation proclaimed by Jesus Christ, they tell the story of his life, his sacrifice and his resurrection, and so they also are the materialization of the divine Verb. As such, they play a central role in christian liturgy: the deacon carries the Gospels during processions, and puts them at the centre of the altar. In the East, from the fourth century, the Gospels are placed on an episcopal throne during ceremonies.

\section{Purple in the manuscripts produced by the school of Charlemagne's court}

Saint-Médard de Soissons's Gospels are incontestably from the school of Charlemagne's court. They were made around 800 , on non-purple parchment, but with purple

\footnotetext{
${ }^{1}$ Daniel 5:29.

2 Mark 15:17.

${ }^{3}$ John 19:2.
}

\footnotetext{
${ }^{4}$ Patrologia Latina 111, col. 563.

5 Patrologia Latina 107, col. 214.
} 
title pages, script, and golden initials, and were offered to the éponyme abbey by Louis the Pious. They feature an illustration of saint Mark and his symbol the lion, both holding Gospel books. The two books in this illustration feature purple pages, and bear the first words of the Gospel. These two books are represented with such luxury and minutia that they immediately draw the viewer in, attesting the highly symbolic value of purple manuscripts during the Carolingian era.

This exceptional status of the Gospel leads to the production of ostentatious books. Their sumptuosity and richness are a tangible indication of Christianity's triumph. These books are designed to impress those who see them, and thus they are produced using the most valuable materials, such as gold and silver inks, and purple to dye pages.

The sixth century corresponds to the Golden Age of the production of purple codices, although a few examples can be found earlier and later. This technique is reserved to Christian aristocracy, and similarly to purple liturgical garments, these manuscripts are criticized by saintJerome and saint John Chrysostom who argue against this luxurious practice, far removed from the simplicity upheld by early Christians. These manuscripts are usually produced for cathedrals, where some of them have remained to this day. The exceptional Codex Argenteus was made for the Ostrogoth king Theodoric the Great, who had re-established the imperial privilege on purple dyes $[16,17]$. In the Latin world, the production of these ostentatious manuscripts seems to fade at the end of the sixth century. The Liber Comitis-BnF latin 945-of Monza or Verona is a late example, produced in the eighth century. Several reasons may explain this decrease: the clientele and the scriptoria working for it tend to disappear during that period, the material used to make purple becomes more and more scarce, and the techniques to create the dye seem to be forgotten.

The Carolingian dynasty reinvigorated the production of purple manuscripts. Again, this production is exclusively focused on Gospel books used during mass, for the same reasons as in the previous era, but also because Charlemagne's reign marks the beginning of a series of liturgical reforms that follow roman rituals more closely. Biblical texts are reinterpreted in the Empire's intellectual centers. The Gospels are scrupulously edited following saint-Jerome's Vulgate, and the Capitulare evangeliarum-a list of pericopes giving the excerpts of evangelical readings following the liturgical calendar-is added to Gospel books. One of the results is the creation of the evangelistary: a liturgical book exclusively dedicated to rituals, that follows the liturgical calendar with extracts from the Gospel corresponding to each liturgical day.
The Godescalc Evangelistary is one of the rare examples of this liturgical reform. The dedicatory poem in the manuscript indicates that it was commissioned by the Emperor and his wife Hildegard, and made between 781 and 783 by Godescalc, Charlemagne's servant. The text is entirely copied in gold and silver uncial letters, framed in purple parchment. It is illuminated with sumptuous fullpage paintings representing the four evangelists, Christ in majesty, and a fountain of life inserted at the beginning of the manuscript. It is the first manuscript from the school of Charlemagne's court to introduce the use of purple in order to enhance the text of the Gospels and their illustrations. Godescalc points out in the dedicatory poempublished in Latin or German [18] or French [19]-the symbolic value of purple in Gospel books: Godescalc's verses underline the double meaning of purple, symbolizing both the divine and human nature of Christ. His visual analogy with blood ties purple to Christ and the martyrs' sacrifice. Similarly to gold, purple is promising the Kingdom of God. In the later verses, Godescalc indicates that the manuscript was produced for Charlemagne and Hildegard, and evokes the Emperor's visit to Rome for Easter in the year 781. In this specific political and religious context, purple also evokes imperial power. Using purple dye in a manuscript after a trip to visit the Pope in Rome clearly demonstrates that Charlemagne aims to create a continuity between him and Christian Roman emperors, who were using purple as a symbolic attribute.

Saint-Riquier's Gospels follow the same principles (Fig. 1). Like Godescalc Evangelistary, it is a product of the school at Charlemagne's court. Their presence at Saint-Riquier is documented in the early years of the ninth century. Charlemagne probably gifted this manuscript to Angilbert, abbot of Saint-Riquier, when the Emperor visited the abbey in 800 for Easter. The abbey had just been rebuilt and three sanctuaries had been consecrated to respond to liturgical needs. Like the Godescalc Evangelistary, Saint-Riquier's manuscript is luxuriously transcribed in gold uncials on purple parchment. Only the list of evangelical pericopes is written in Caroline minuscule on blank parchment. The titles are transcribed in orange-red ink, or, more rarley, in silver ink. In Antiquity, it was common to associate minimum-the pigment yielding orange-red colors-with purple in manuscripts and mural paintings [20,21]. The presence of this association in a manuscript from the school of Charlemagne's court echoes the decorations, heavily influenced by antique art, and indicates how the ostentatious production of the era emulated antique productions and used them as reference. These two manuscripts are the only preserved specimens featuring fully purple pages dating from Charlemagne's reign. It si is 


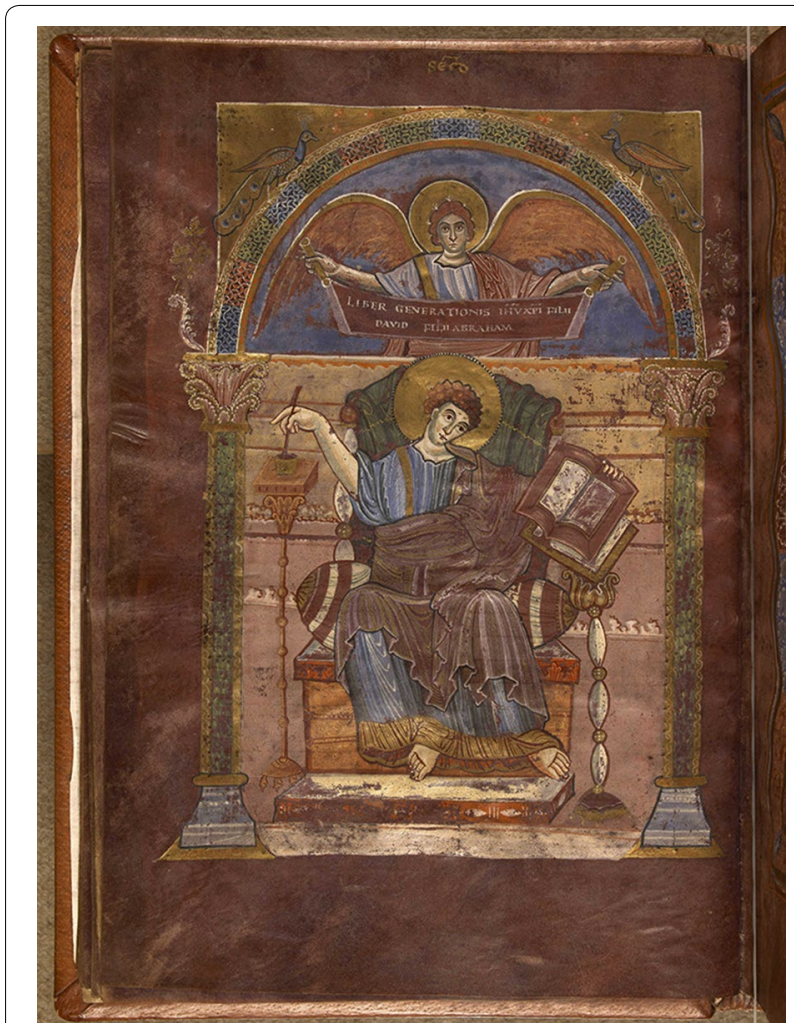

Fig. 1 Saint Matthews' portrait, Saint Riquier's Gospels, folio 17v, Abbeville, MS004

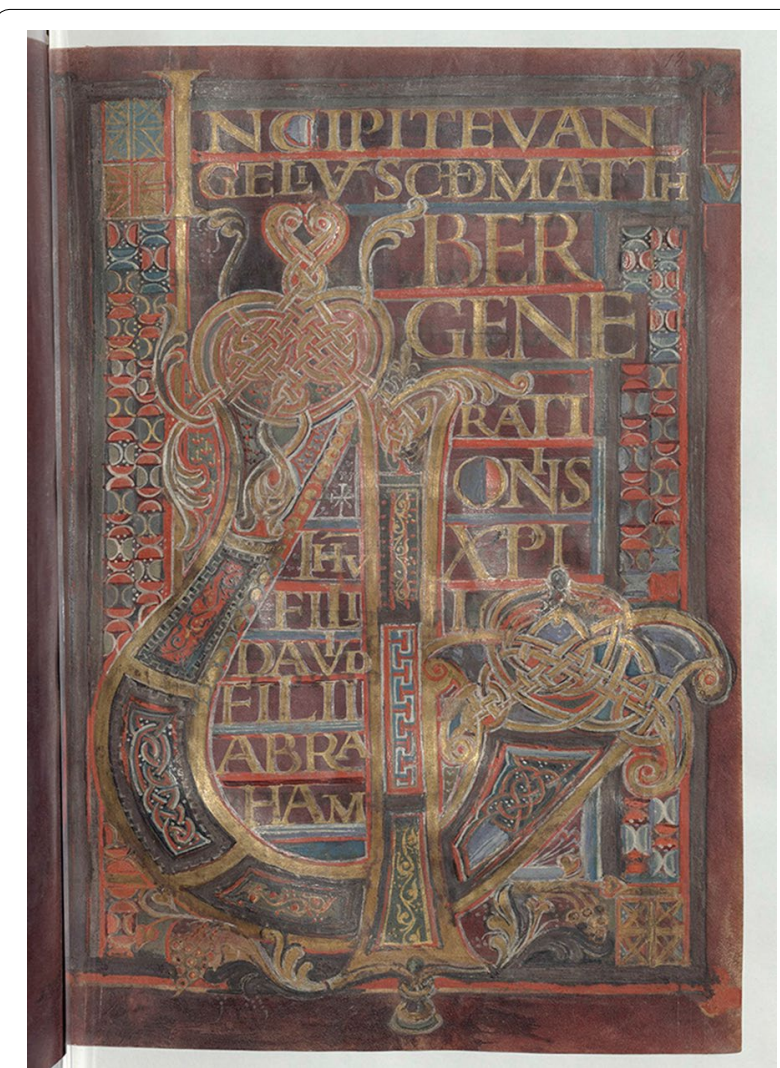

Fig. 2 Incipit page, Saint Denis's Gospels, folio18r, BnF, latin 9387 also the case of a third manuscript the Vienna Coronation Gospels because the legend says that they are discovered in the thousand year by Otton III, on Charlemagne's knees, when he proceeded to the opening of its grave. Afterward, these Gospels were used during the ceremonies of the crowning of the Ottoniens emperors, in reference to Charlemagne. By their character of splendor and some lines of the decorative decoration, they are related to the school of Charlemagne's court, but they distance themselves from it by their textual tradition and the style very different from the writing onciale and of the figurative decoration which are unprecedented in the production of the school of the court. The decoration translates a pictorial current illusionist stemming from the Hellenistic art. The Vienna Coronation Gospels manuscriptmade in the very last years of the eighth century, also using the same noble materials that are purple, gold, and silver-were recently analysed [22, 23]. However, its style strongly differs from the other two purple manuscripts and would tend to indicate that it belongs to another group altogether. Still, these three Gospels manuscripts are the only purple manuscripts remaining from Charlemagne's reign.
The luxurious Gospels book offered by Charles the Bald to the Saint-Denis abbey (Fig. 2) can be put in the same category, although its date is still debated [2]. Yet, the text in silver minuscule and rubrics in gold capitals tie it to the school of Charlemagne's court.

In other manuscripts, purple was also used to highlight important parts, such as the canon of the Mass in sacramentaries or psalms and gospels in Theodulf's bibles. Among them, the one kept in Paris was analysed [24] (Fig. 3). Purple may have also been used in framing some pages.

This tradition of using purple in liturgical manuscripts continues under the dynasty of the Ottonian emperors, who consolidate their image as heirs of carolingian emperors. Some rare examples emerge out of West Francia in the beginning of the eleventh century, for instance the Gaignières Evangelistary (BnF latin 1126), Beauvais sacramentary (Los Angeles, Getty Museum, 83 MF 76), or the Arsenal Gospels (BnF, Arsenal, ms. 592).

\section{Study design and methods}

In France Bernard Guineau and Jean Vezin conducted pioneer studies on color materials in the 1990s, which continued under a new team at the Ernest-Babelon 


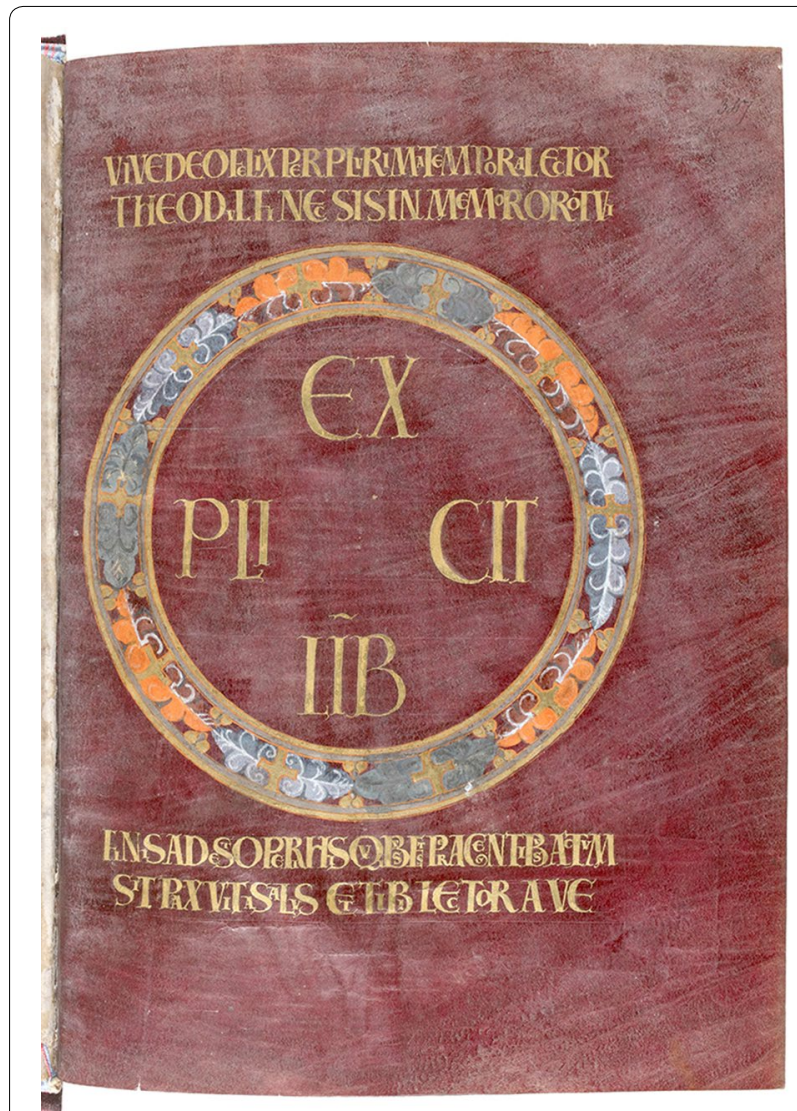

Fig. 3 Explicit page, Theodulf's Bibles, folio347r, BnF, latin 9380

center [French Research National Institute on Archaeological Materials (CNRS)] in Orleans. These interdisciplinary studies are designed to answer historical questions, and are producted in collaboration between historians specialized in the Medieval and Renaissance eras, art historians, codicologists, curators, and physicists. In this particular study, we used magnified examination and spectrometric analysis of the pigments to ensure better the materials and techniques medieval artists used to create these purple manuscripts. This knowledge then enables conservators to better ensure their preservation [25-28].

In Gospels books, illuminations and decorations often correspond to Eusebius of Caesarea's canon tables (Figs. 4, 5, 6)-Theodulf's bible also features some impressive ones in folios $3 \mathrm{v}$ then 248 to 253 and f $348 \mathrm{v}-$ (Fig. 7). The featured Evangelists' portraits: NAL1203 (fol.1, 1v, 2, 2v), ms004 Abbeville (fol. 17v, 66v, 102, 153v), lat.8850 (fol.17v, 82v, 123v, 180v) (Figs. 1, 8) correspond to an ancient insular tradition, and so do the Incipit pages: ms004 Abbeville (fol.18, 67, 102, 154), lat.9387 (fol.18, 85v-86, 127v-128), lat.8850 (fol.18, 82, 124, 181) (see Figs. 2, 9, 10, 11). Although similar in style, these

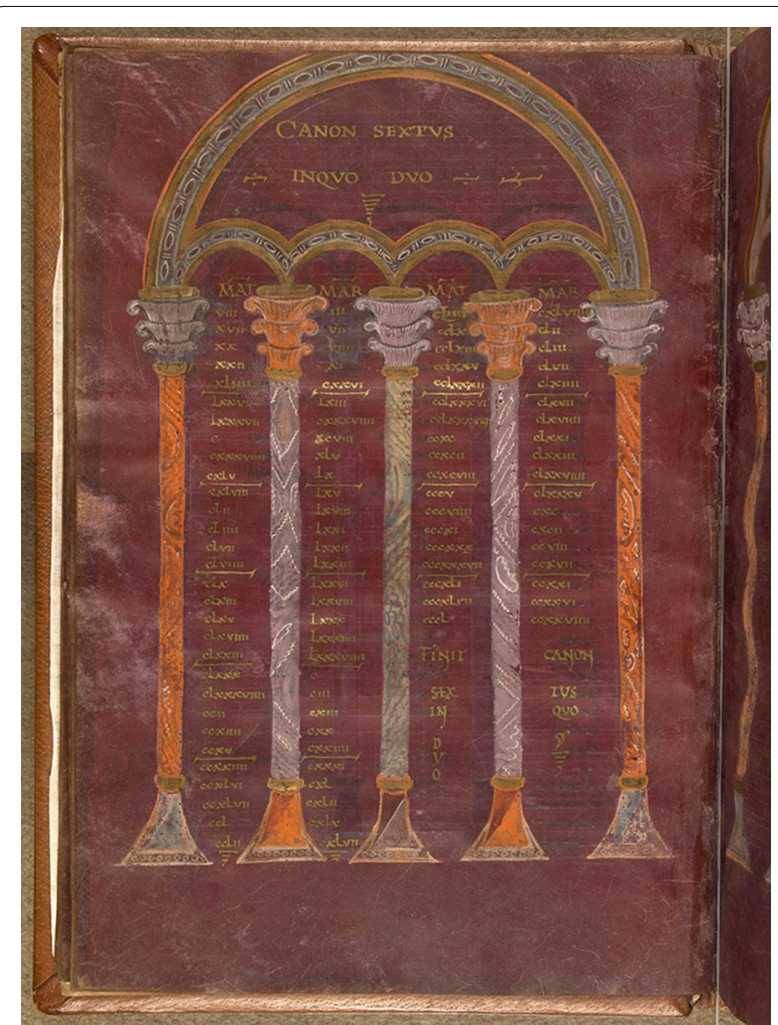

Fig. 4 Saint Riquier's Gospels, folio 14v, Abbeville, MS004

paintings demonstrate a great variety of decorations (foliage friezes, interlacing, arabesques, mosaics and herringbone patterns), evoking the richest book bindings. This diversity appears by merely comparing capitals and tympanum, but the stylistic convergence between these manuscripts remains striking nonetheless. Although the color palette is similar from one manuscript to another, Saint-Médard de Soissons's Gospels show a wider range of hues used in magnificent paintings of tympanum in vaulted ceilings, where the color purple is strategically applied-in folio 7 for a gold and purple book; folio $8 \mathrm{v}$ for the banner and a beautiful cameo sky-.

Some illuminations are specific to this corpus: the Godescalc Evangelistary features two new themes: folio 3, Christ (Fig. 12) and folio 3v for the first time in Occident, the illumination representing a Fontain of life (Fig. 13); the last one is also taken up in Saint-Médard de Soissons Gospels in folio 6v (Fig. 14).

Vieillard-Troïekoff describes the similitude between the few and aniconic decorations in Theodulf's bibles [29]. Although there is only one decoration-at folio $154 \mathrm{v}-$ in the manuscript lat.11937 (Fig. 15), its resemblance to the decoration on folio 286v of manuscript lat.9380 is quite striking (Fig. 16). Vieillard-Troïekouroff suggested they were based on the same models. The blue, light 


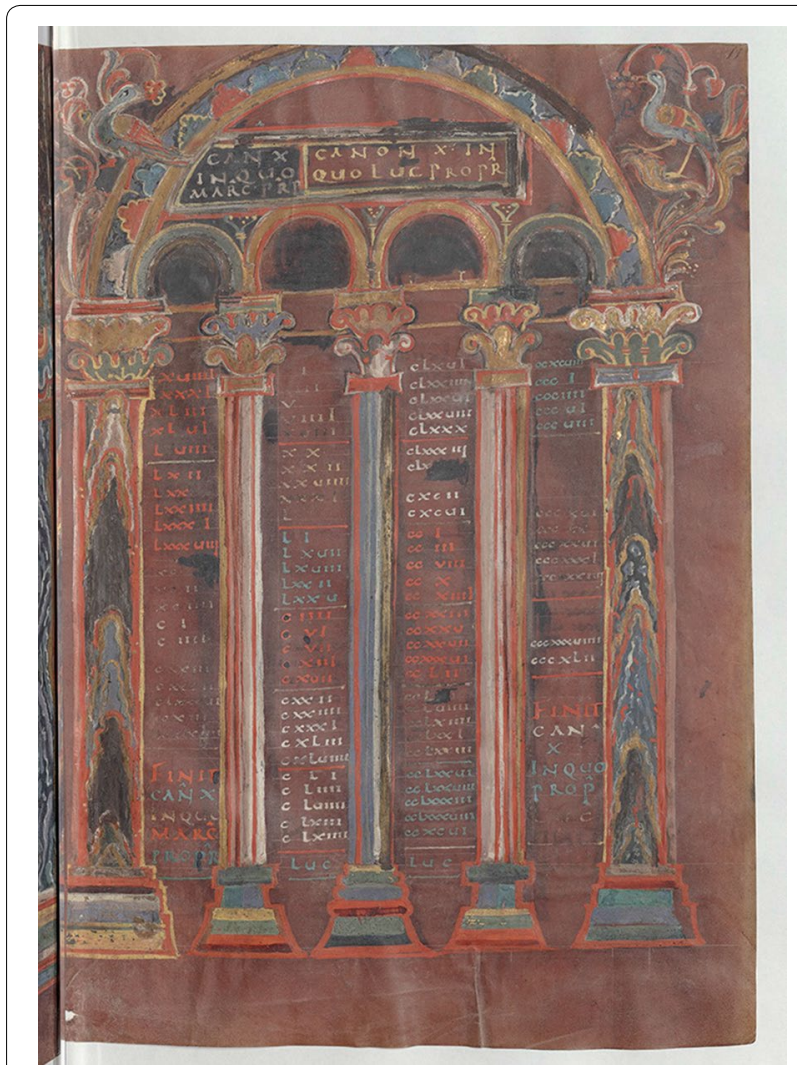

Fig. 5 Saint Denis's Gospels, folio1 1r, BnF, latin 9387

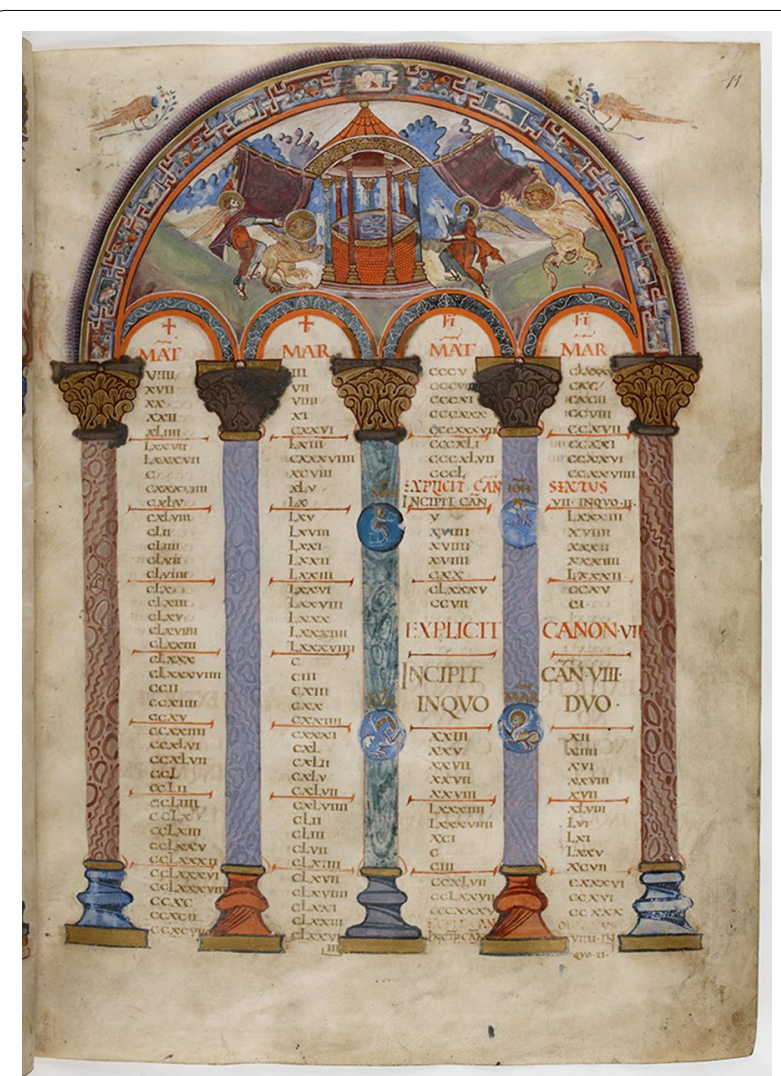

Fig. 6 Saint Medard de Soissons's Gospels, folio 11 r, BnF, latin 8850 blue, white, orange, purple, green, and yellow palettes are similar, and so are the materials used. Manuscript lat.9380 uses gold circles rather than silver, which points to its higher value. This manuscript also features purple pages with gold text. This Bible has a "twin" manuscript preserved in the Puy-en-Velay's Cathedral which constitutes a part of the treasure, both Bibles were described by Leopold Delisle in a note of the Ecole des chartes Library (XL, 1879) read to the Institute in July, 1878 [30], it also talked about the manuscript lat 11937. The two manuscripts feature the same materials and a strikingly similar execution. This leads us to relate these two bibles to a common workshop, under Theodulf's direction. Vieillard-Troïekouroff and L. Delisle also identified Theodulf as the author of the Libri carolini $[31,32]$.

\section{Analytical equipment StereoMicroscopy observations}

The colored surfaces were observed on site with the Stereomicroscope Leitz-Wild M5A. Views were captured by a TriCCD camera and also by a Nikon D200.

\section{$X$-ray fluorescence}

On site analysis on manuscripts was carried out at the $\mathrm{BnF}$ and at the libraries of Abbeville and Orleans using a Bruker Artax X-ray Fluorescence. This spectrometer is composed by a X-ray tube with a Molybdenum anticathode and a detector XFlash. The X-ray tube was equipped with a $0.65 \mathrm{~mm}$ collimator. The spectrometer was run in air at a constant fixed distance and performed with no filter, it was using the dual condition sets of $45 \mathrm{kV} / 800 \mu \mathrm{A}$. The measurements lasted $60 \mathrm{~s}-$ and $120 \mathrm{~s}$ for the metallic pigments-acquisition and performed with no filter. Analysis was made with a non-fluorescing background plate placed under the verso paper substrate so as not to pick up elements from the next folio. A measurement of the parchment substrate from each page was taken and spectra from the colored surface and natural parchment were overlaid.

\section{Vis/NIR fiber optic reflectance spectroscopy (FORS)}

Analysis was carried on site with visible and near infrared fiber optic reflectance spectroscopy for the identification of organic and mineral pigment on manuscripts of each Library. A mobile Oriel Instaspec spectrograph with an interchangeable grating in Czerny-Turner and a 


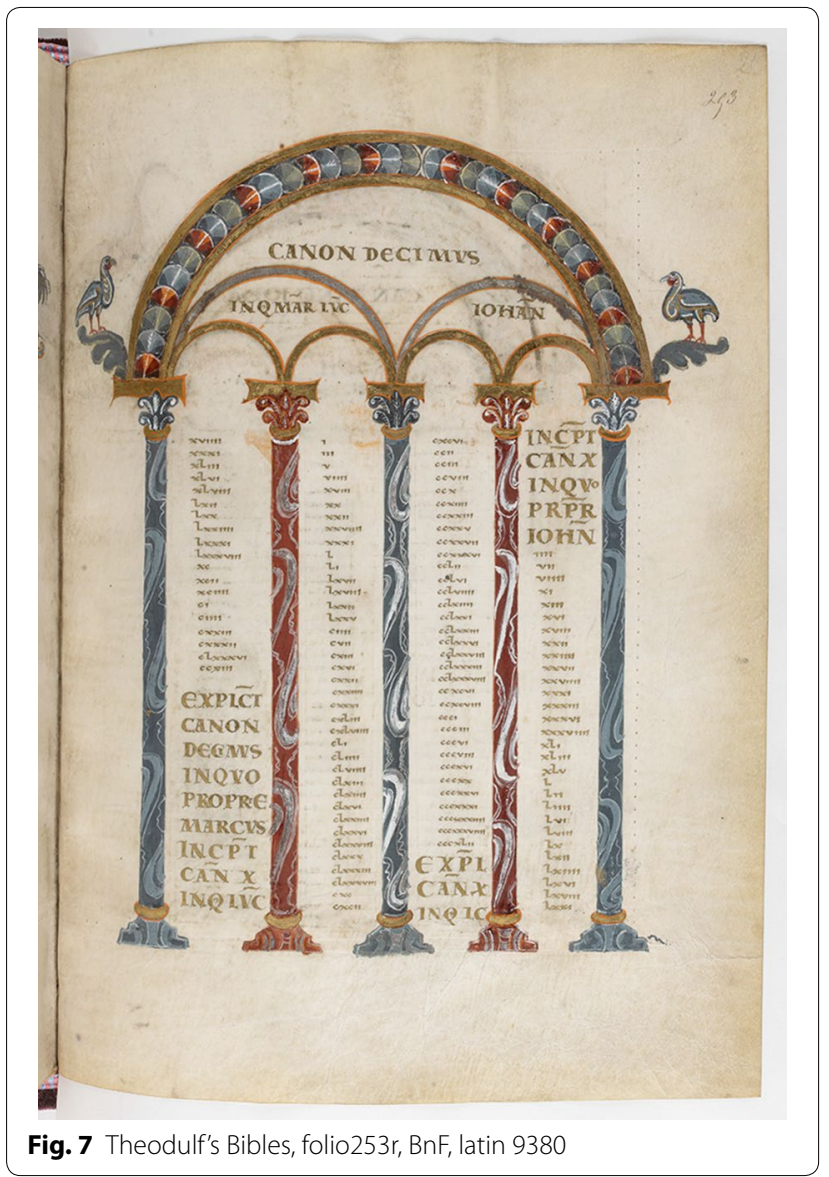

1024 diode array detector was carried out for exploring the spectral range of $380-830 \mathrm{~nm}$. Measurements were taken with a $400 \mathrm{~nm}$ grating/25 $\mu \mathrm{m}$ entrance slit for a $0.6 \mathrm{~nm}$ spectral resolution. 100 scans were acquired for each spectrum for a total acquisition time of $100 \mathrm{~s}$ and with a quartz tungsten halogen light source of $150 \mathrm{~W}$. Another mobile Ocean Optics 2000 spectrophotometer unit with a spectral range of 300-1100 nm was used, equiped with a 2048 array ccd detector, a fix $300 \mathrm{~nm}$ grating/50 $\mu \mathrm{m}$ entrance slit. 50 scans were acquired for a total acquisition time of $40 \mathrm{~s}$ with an HL2000 tungsten halogen light source. Each FORS was equipped with an Y fibers probe used parallel to the surface with a mylar protected sheet. A diffuse white standard was used to calibrate the instrument. Spectrometer was run first on $\mathrm{MgO}$ reference and then on coloured surfaces. Our measurements were compared to our references samples.

Our folium references samples has been made with Folium provided by the KREMER company.

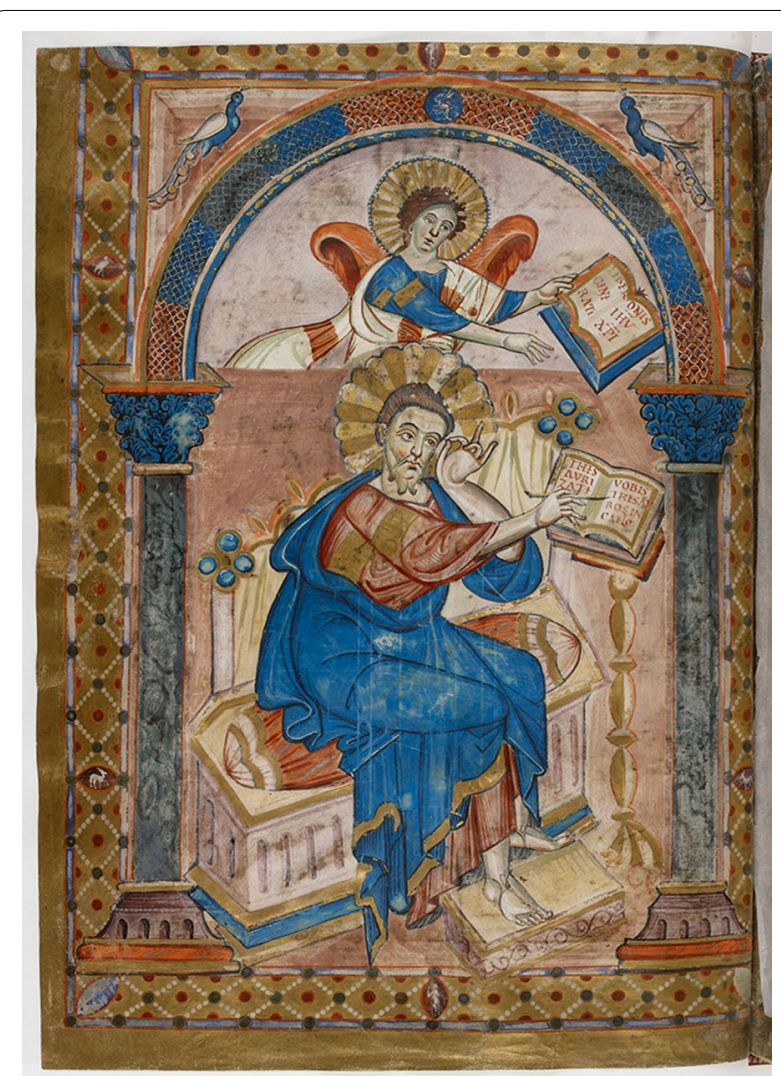

Fig. 8 Saint Matthews' portrait, Saint Medard de Soissons's Gospels, folio 17v, BnF, latin 8850

\section{Results and discussion \\ The purple colour}

What is the coloring agent producing the purple on the folios? After measuring the manuscripts, we compared these results with reference substances. Red dyes such as madder, cochineal-kermès, and lac-dye, were quickly put aside, since their spectral profiles were too different from the measurements made on the manuscript. Our results showed that the purple color in lat.11937's decorations is similar to purple parchment in lat.9380. These colours, also called folium, were most likely obtained from Chrozophora tinctoria a tinctorial plant in the Euphorbiaceae genus, growing in the Mediterranean region referred to the Bernard Guineau's work [25] and to the results of analysis made by Flieder [33],-it referred also to those undertaken by a team of the Research laboratory on Historic monuments, LRMH Champ-sur-Marne working with the department for the restoration of the BnF, which concluded that colouring agents derivatives of orcinol that we can find either in orchils or in Chrozophora tinctoria L. were present [24, 34]; and it referred to the work of Fuchs and Oltrogge [21] —. This dye was used several times decorating the Fleury manuscripts in the 10th and 


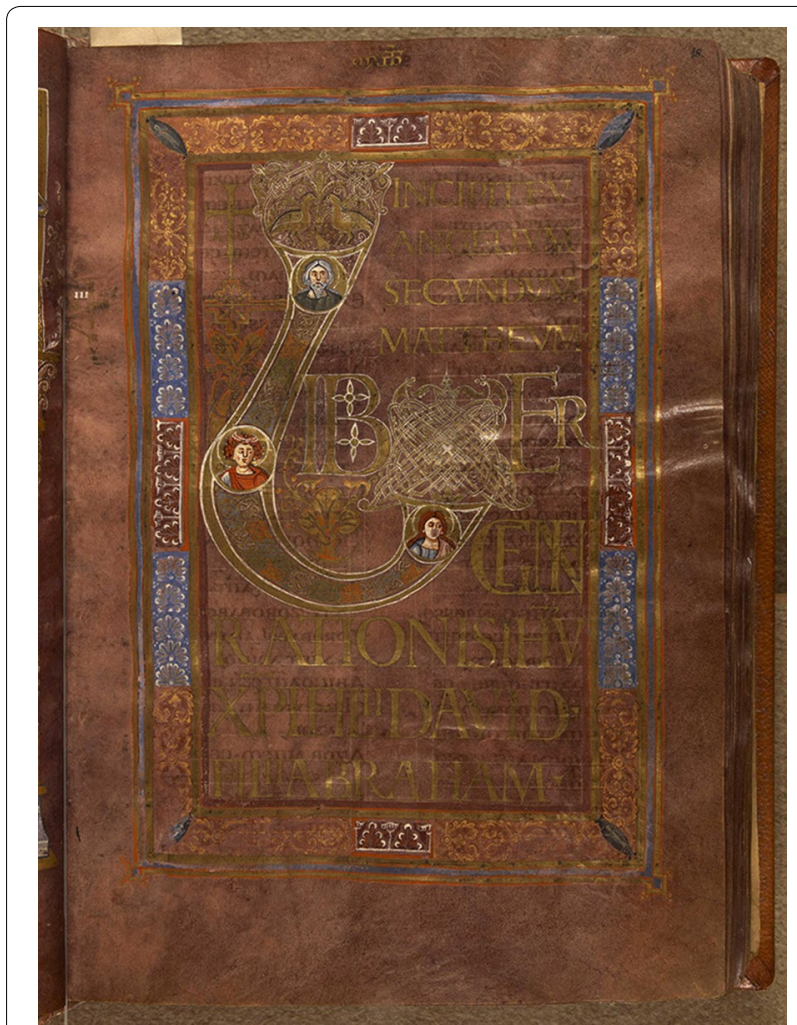

Fig. 9 Incipit page, Saint Riquier's Gospels, folio 18r, Abbeville, MS004

11th centuries (Orléans BM.127 and 145), and it was identified in older manuscripts as well using the same method, as indicated in Guineau's studies (BNF lat.7520, lat.2421; Amiens BM.11, 18, 223; Vatican reg.lat.124). In his papers, Guineau indicates that the word "folium" was often used in technical treaties as early as the 9th century, including in the Mappae Clavicula, to describe a purple colour, although folium can also produce shades of pink that can go towards red or blue. We also observed these variations on the manuscripts we studied. A treatise preserved in London indicates the origins of folium: this helped Merrifield and other authors to identify Chrozophora tinctoria. Its use declines later in the Middle Age [35]. It seems to disappear from recipes of colour treatrises from the 14th century for the benefit of the easier to find colouring agents: madder, kermès, brésil.

Folium had various meanings in the past. It could indicate: "a piece of woven cloth soaked with the dye on which it was stored for its preservation.". It could be called sunflower: Nissole (1712) describes a manufacturing process of the sunflower in flags, consisting in "extracting the juice of the plants, dipping rags there which are left to dry, then soaking them in a vessel full of urine and redipping them into the liquid, and drying them for transport" $[25,36]$.

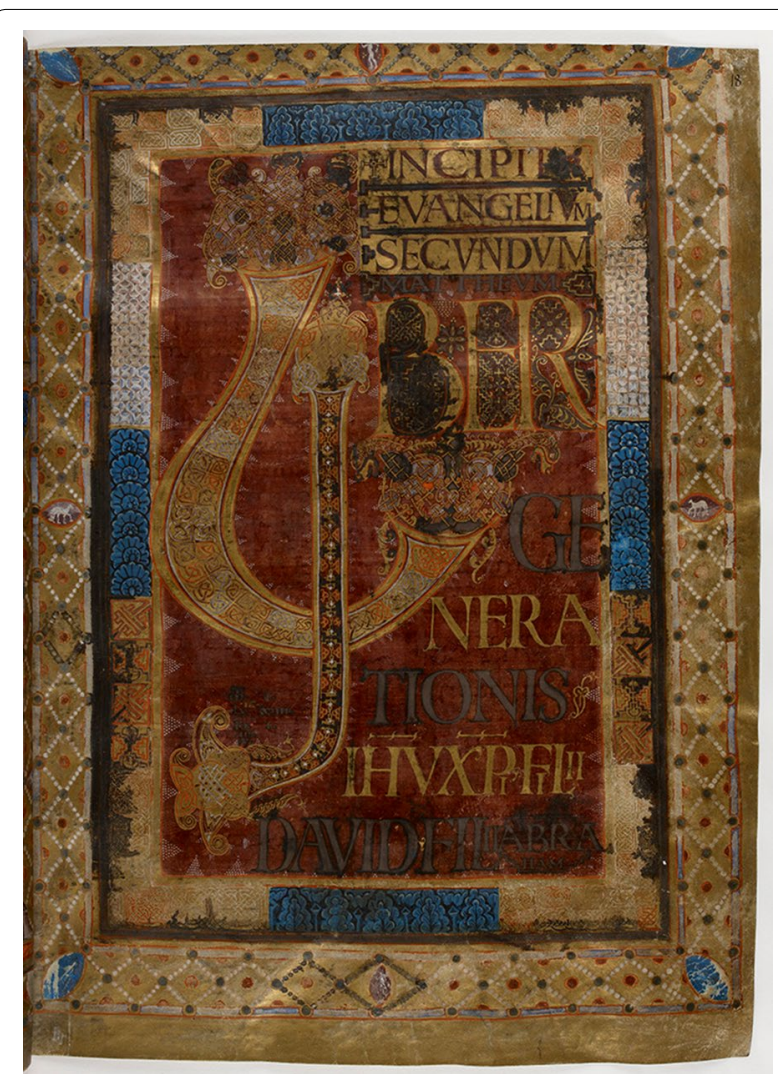

Fig. 10 Incipit page, Saint Medard de Soissons's Gospels, folio 18r, BnF, latin 8850

To know more about the coloring agent used for the purple colour on the manuscripts of our corpus, we have used entirely natural parchments made by Anne-Marie Guin-Brunet to establish folium dyed references. -Others coloured purple parchments were precedently dyed by Inge Boesken-Kanold with purple from the Hexaplex Trunculus a mollusk collected on the Mediterranean Coasts [5, 37]. This animal supplies all of the colouring agents that we can find in shells suppliers of the purple that is the pinkle-red $6,6^{\prime}$ dibromoindigotine dibromoindigotine, the purple-blue 6bromoindigotine as well as the indigotine and the indirubine. Other were dyed by Isabella Whithworth with the Lasallia Pustula lichenorchil $^{6}$-. These references (Fig. 17) were measured and their curves compared (Fig. 18). Then curves measures on manuscripts were compared to our references curves (Fig. 19).

The result was that orchils or folium substitutes were used instead of the famous purple for all the manuscripts

\footnotetext{
${ }^{6}$ We specially thank Inge and Isabella very much for their generosity.
} 


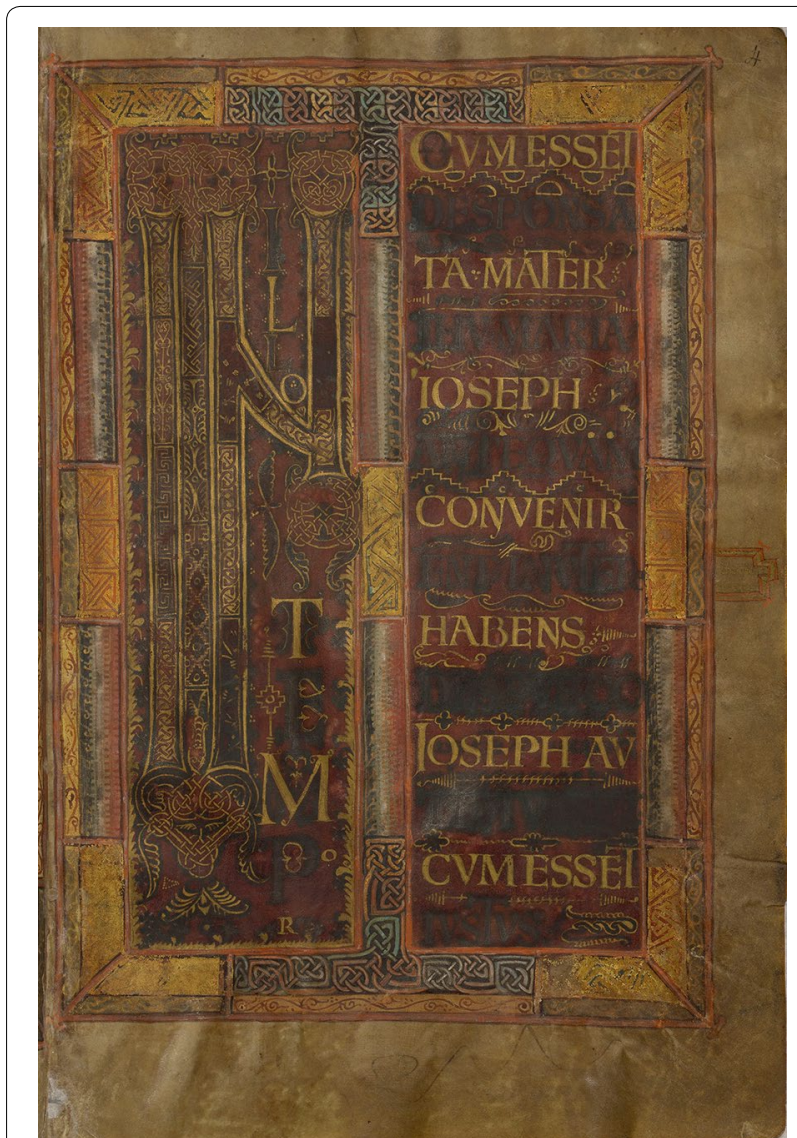

Fig. 11 Incipit page, Godescalc Evangelistary, folio 4r, BnF, NAL1203

of our corpus-whether they were completely purple or not.

Differences in the shade of some compared to others were attributed to the preparation techniques: the acid or basic immediate environment of pages; the initial preparation of the dye; and the technique used to apply to colour onto the parchment.

We also wondered about the ways to obtain partially coloured parchments as observed on the Godescalc Evangelistary (BnF NAL 1203).

Anne-Marie Brunet and Siloe tested various ways to colour by brushing and soaking, but the results did not seem conclusive: the paint left some brushstrokes marks and the immersion must be realised in particular conditions of temperatures. Pages absorb the dye differently on to the flesh side than on the hair side. Very often, one of the sides is badly dyed and the parchment may become very stiff. A third way, quoted in a work presenting the manuscript of Abbeville: “... one could recognized the way of dyeing the vellum, what was to place a sheet of vellum between two pieces of linen with that colour soaked, that we put under the press. Indeed, several are still printed by

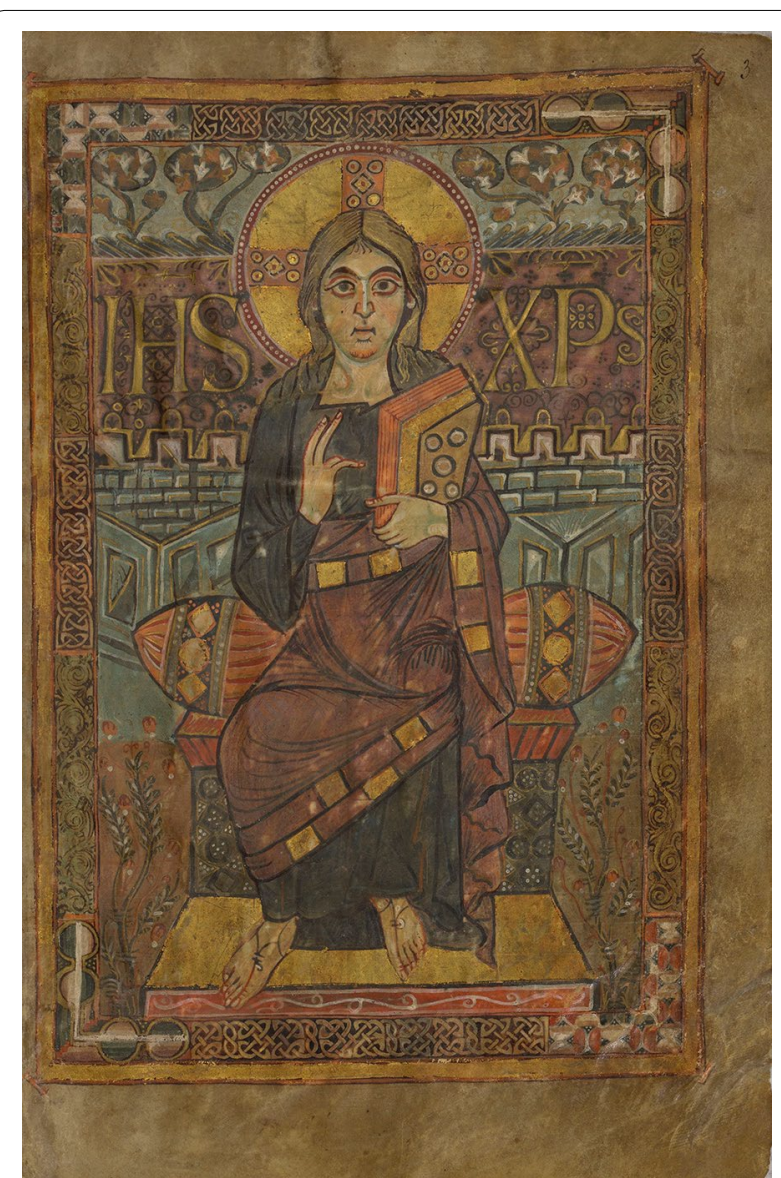

Fig. 12 Christ in majesty, Godescalc Evangelistary, folio3r, BnF, NAL1203

the texture of the canvas" [38], was not yet explored: dyeing with a press.

We therefore made a variety of new samples, to understand better the technique necessary to reach a correct result. In the end, we established a protocol according to the observations made in St. Riquier Gospels. ${ }^{7}$

That method we named "à la presse", because of visible marks remaining on the pages, was used to colour the pages of St. Riquier's Gospels (Fig. 20) -this is particularly visible in folios $18 \mathrm{v}, 19 \mathrm{r}, 20 \mathrm{v}$ and $23,29 \mathrm{v}-$. It has several advantages: this technique is easily practiced, the transport of the dye "captured" in a cloth remains easy, the parchment keeps its flexibility, it is possible to colour several pages at the same time and it is possible to colour only a part if the size of the dyeing cloth is the same as the part of page that we try to colour (Fig. 21). This

\footnotetext{
${ }^{7}$ We thank Marie-Noe Hue who allowed us to make observations on this manuscript and comparisons with our references.
} 


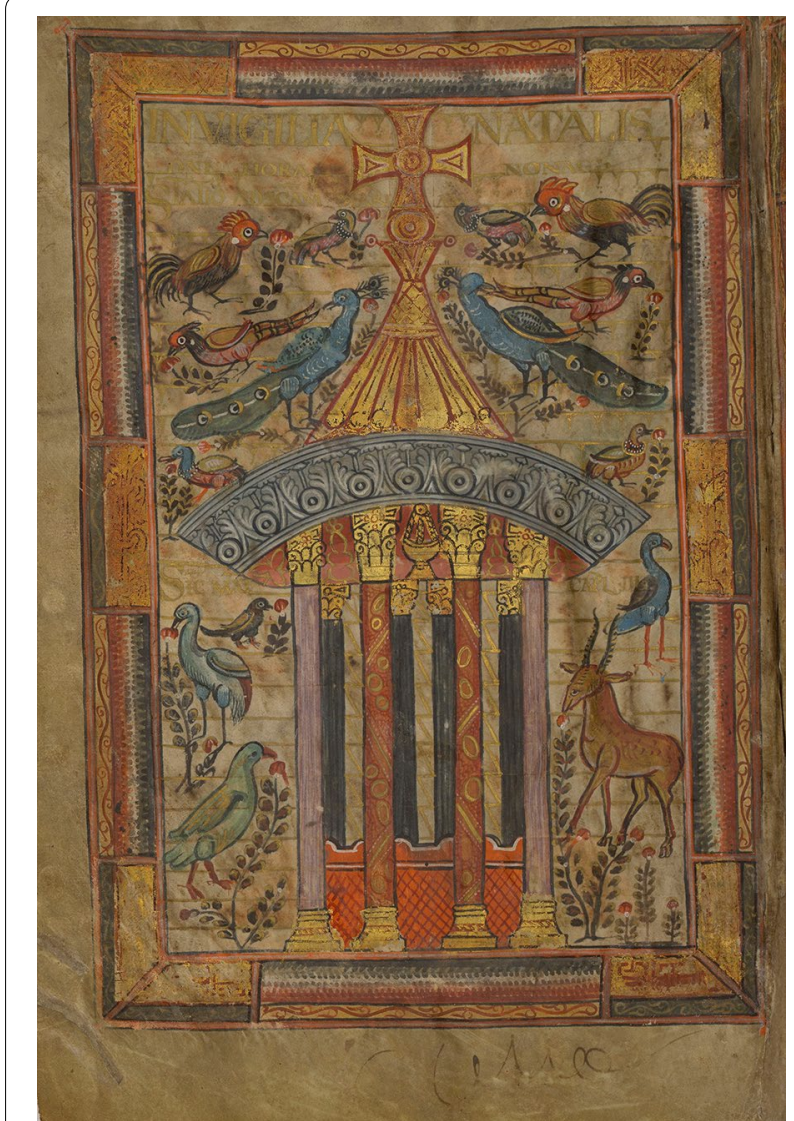

Fig. 13 Fountain of life, Godescalc Evangelistary, folio3v, BnF, NAL1203

method could also be used to dye the central part of the Godescalc Gospels's parchment.

\section{The other colours}

If we compare the tables of the canons in the Theodulf's Bible (lat.9380), in St. Médard de Soissons's Gospels (lat.8850) or St. Denis's Gospels (lat.9387) St. Riquier's Gospels (ms004), the illuminations of the Evangelists in the Godescalc Evangelistary (NAL.1203), and those of the Incipit, we observe a common range of colours: purple-pink, blue, orange, green or blue-green, yellow, white, black, golden, red or brown-red. Analyses allow to specify the shared materials that were used: woad-indigo; orpiment; orange's lead (except for lat.9387); foliumorchil; white's lead; green compound of woad-indigo and orpiment; and carbon black. These analyses also show that the Gospels use a wider range of materials than the Bibles (Table 1). Our experimental study also allowed us to understand that the use of little plentiful pigments on a purple bottom allowed the artists to give an effect of transparency as we had observed it in St. Riquier's Gospels.

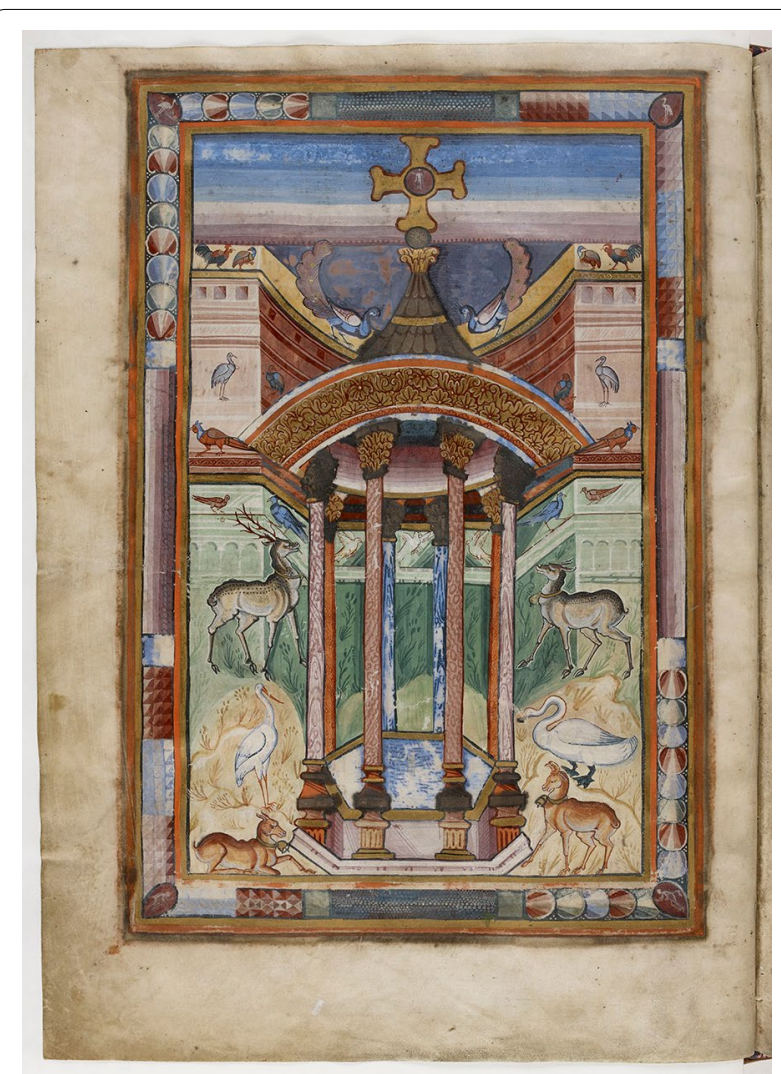

Fig. 14 Fountain of life, Saint Medard de Soissons's Gospels, folio6v, BnF, latin 8850

\section{The text and the metal pigments}

Decorations and gilded and silvered texts are made of metal alloys and the XRF analysis does not show any underlayer. Pure gold is exceptionally used to the illumination of the folio 3 in the Godescalc Evangelistary (Table 2). This can point to difficulties in supplying raw material, or indicate an economically deliberate choice regarding the production of these manuscripts during Charlemagne's reign. Numismatics analysis of Sarah [39] show us that silver coins under Charlemagne used the lowest the content of silver during this period, before the reform in 794, it could be attested by the second hypothesis.

We also wondered about the technique that could be used by copyists and illuminators to write with gold and silver on the purple parchments. We have constituted golden and silvered references layers (Fig. 22) in the light of ancient texts relative to the art of the illumination [35, 40, 41]. That enabled us to compare them with St. Riquier's Gospels and it appears that the copyist wrote with a quill in a gold ink. Inks were prepared in a simple way without any underlayer, with a binder, which could be arabic gum, fish glue, oxgall, garlic juice or more 


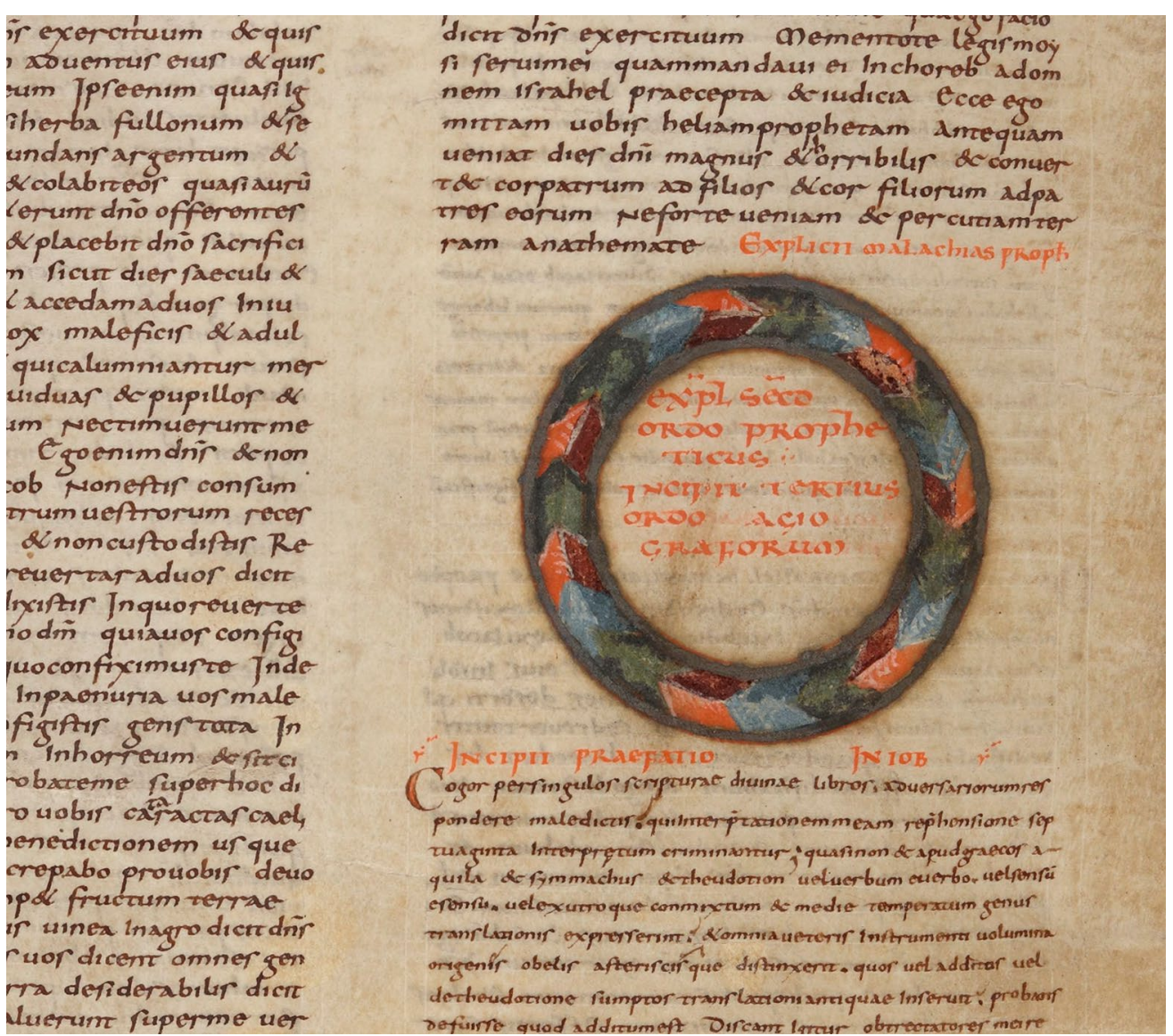

Fig. 15 Explicit page, Theodulf's Bible, folio154v, BnF, latin 11937

probably parchment glue. This last substance offers a remarkable shine without requiring the parchment to be prepared in any particular way. We also noted artistic differences linked to the large decorative initials which are sometimes outlines with gold (Fig. 23) in the St. Riquier's Gospels. They are also edged with folium (Fig. 24) in Godescalc Evangelistary, or with lead white (Fig. 25) in St. Denis's Gospels, showing again the creative range of the artists who have contributed to these pieces.

\section{The fountains of life}

Two of the studied manuscripts feature a representation of a fountain of life: St. Médard de Soissons's Gospels (lat 8850 folio $6 v$-see Fig. 14) and Godescalc Evangelistary (NAL 1203 folio $3 v$-see Fig. 13). They are based on a common model: a similar architecture of a fountain occupies the full center and animals are placed around it according to a hierarchical order. However, the artistic compositions differ. In one case, the fountain is placed in the surrounding of a luxurious palace beneath a bright sky. In the other case, the fountained is placed in a space cleared of any architectural element in the midst of nature represented by flowery vegetable curves, a fauna mainly comprising birds, and a golden text.

The use of soft colours en camaïeu is remarkable in folio 6v (St. Médard de Soissons's Gospels) and all the painting pointed the artists' high technical skills. The use of the purple colour inserted in the gilded cross crowning the dome can suggest his particular spiritual intent. The beautifully painted animals are smaller and smaller, while our look rises towards the top, a subtle way of suggesting perspective.

In the Godescalc Evangelistary, the fountain and animals, each associated to a floral design, occupy the entire space. The illuminator does not paint the water, he directs our look towards the capitals and the shining dome as well as towards the two splendid blue peacocks situated on either sides, and he captures our attention there. 


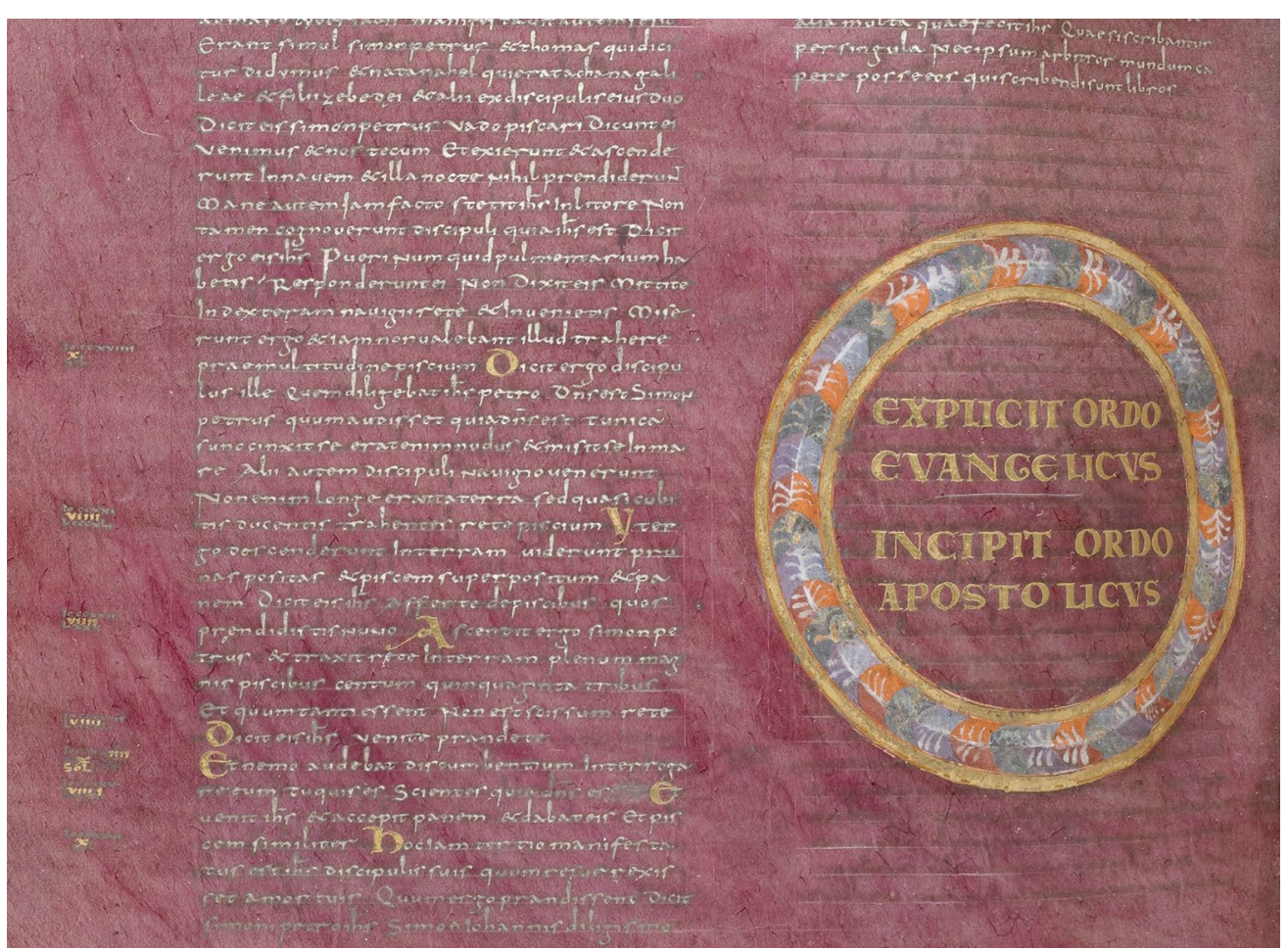

Fig. 16 Decor, Theodulf's Bible, folio286v, BnF, latin 9380

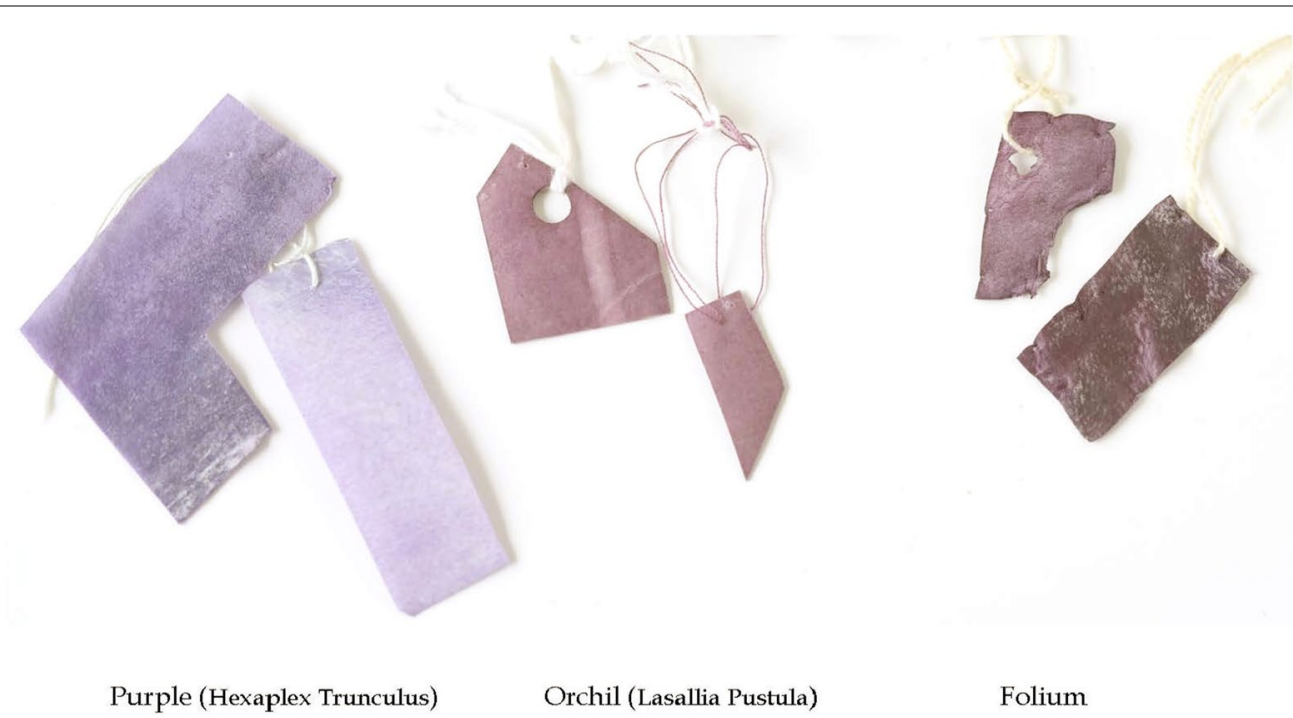

Fig. 17 Samples of dyed parchments with purple (hexaplex trunculus), orchil (lasallia pustula) and folium

A great portion of previously used colouring materials finds itself here in these two illuminations. But, considering the novelty of that iconography in the West and its highly symbolic character, we should underline the selection of blue material for each.
In the St. Médard de Soissons's Gospels, the use of the only lapis lazuli, distinguishes this illumination from the others. In the rest of the manuscript, other blue materials like Azurite and Indigo were employed. 


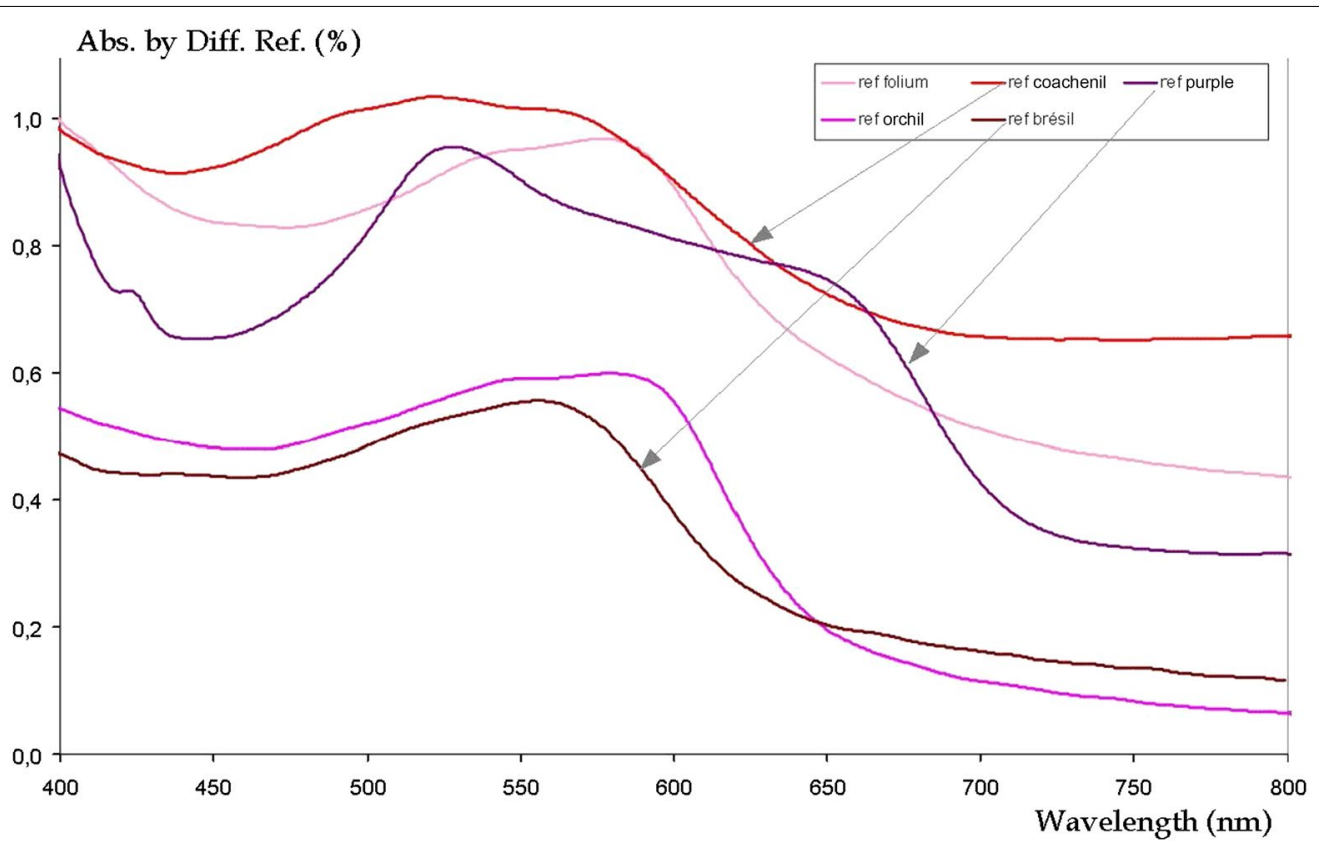

Fig. 18 FORS curves of several red dyes matter on natural references parchments: coachenil, purple, brésil, orchil and folium

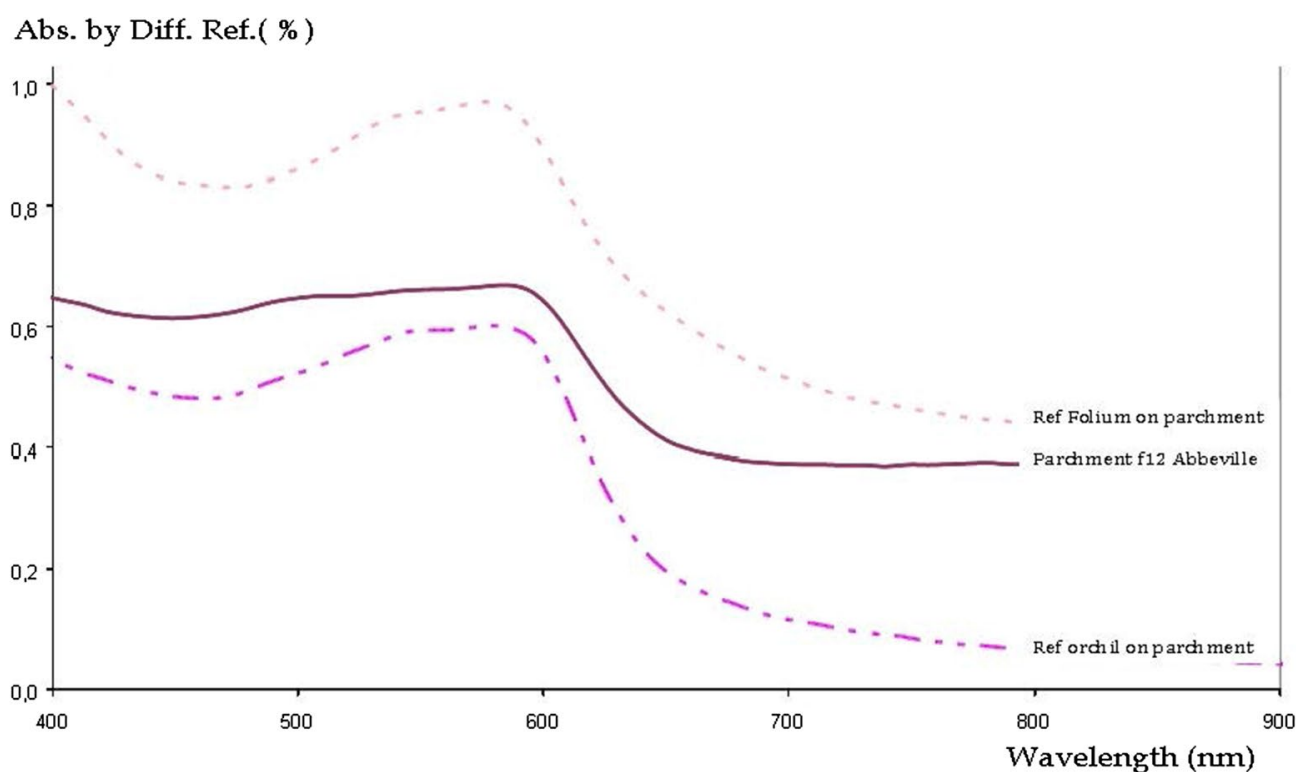

Fig. 19 FORS curves of measurements on purple parchment in Abbeville's manuscript (folio12v), compared to curves of orchil and folium dyed parchments

In the Godescalc Evangelistary, the use of the precious and heavily symbolic Egyptian Blue-a disappearing and extremely rare material for illumination at that periodfor the peacocks bodies (Fig. 26) identifies a specific expertise and perhaps reveals the hand of an oriental artist related to the blue of Pharaohs in their final resting places. In the carolingian Christian world, the powerful symbolism of the color blue appears through Raban 


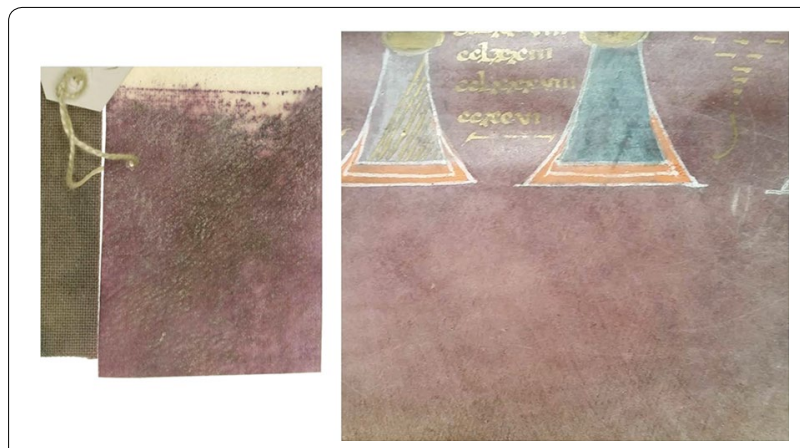

Fig. 20 Sample of parchment dyed "à la presse" and a view of the folio 15v parchment (Saint Riquier's Gospels, Abbeville, MS004) still printed by the texture of the canvas

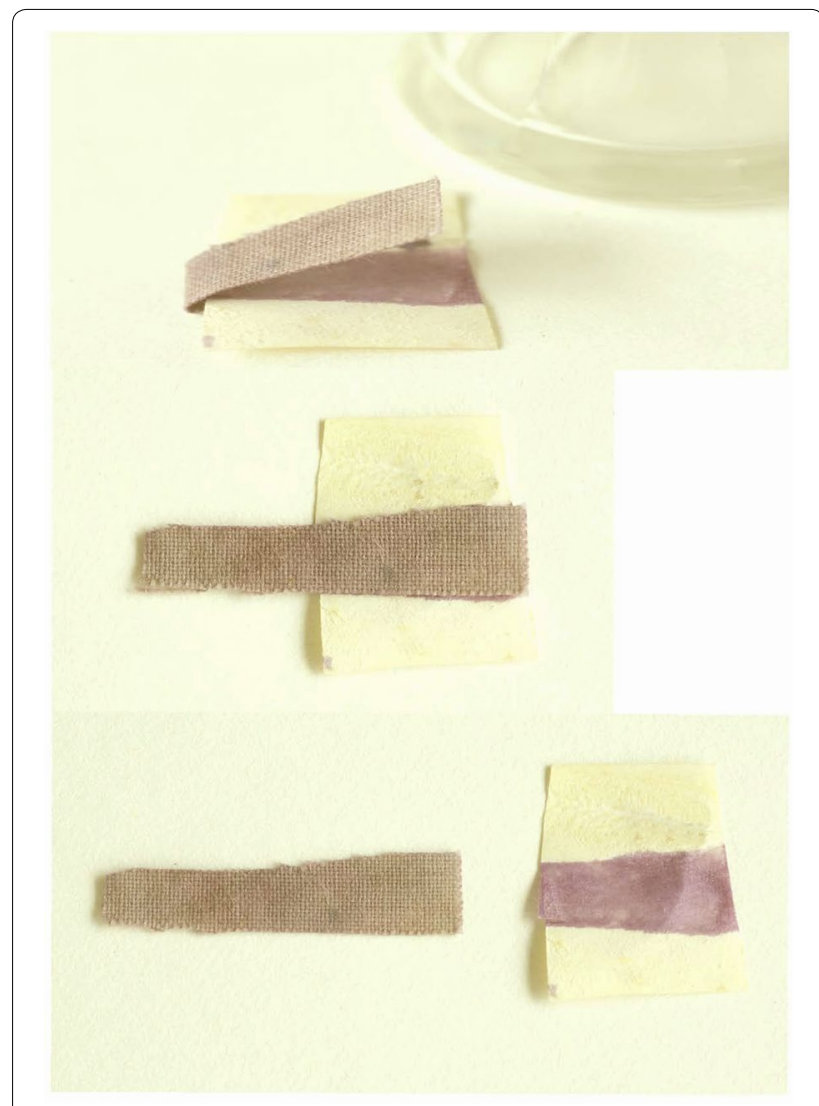

Fig. 21 Example of a sample of parchment partially dyed "à la presse"

Maur and whithin his manuscripts in which the painted coat of the represented Christian emperor is not red purple of the terrestrials vistories but blue of the heavenly space [42]. The remarkable use of Egyptian blue here assigns a very special status to this manuscript.

\section{Conclusions}

The study of our richly decorated corpus of elaborate Carolingian manuscripts has revealed their material similarities and differences. While they may be stylistics similarities, the ways in which artists have achieved their own illuminations are variable from one to another manuscript. It shows how the artists are distancing themselves from their Antique heritage. The analyses of pigments give evidence of the creative phase of renewal which characterises the reign of Charlemagne through the use of a large classic palette and also specific materials as lapis, Egyptian blue, folium or orchil for tinting parchments. The analyses of gold and silver decorations indicate the use of alloys rather than pure metals. This may be due partly to scarcity of natural raw materials or partly to the wish to lower the cost of these contemporary creations.

The purples Gospels's mass production over a very short period is directly related to Charlemagne. Looking at the list of fully purple post-Charlemagne manuscripts, we see that these are often isolated achievements related to a patron or a religious institution. The production of purple codices ordered by Charlemagne results from a royal patronage, similarly to the mass production of Bibles, which Constantin ordered for the churches of Constantinople [43]. This imperial patronage had disappeared since the fall of the Empire and its resurgence corresponds to a very precise religious objective: the new releases of Gospels in connection with the liturgical reform undertaken, based on the Roman models. These new releases are produced by a specialized workshop working for the court or by artists knowing the productions of this workshop.

This production of elaborate manuscripts, as well as the building of the Palatine Chapel, follows a will to revive the Antiquity-not the classical world, but the ancient paleoChristianity-even before Charlemagne was raised to the Imperial dignity in 800. Charlemagne was not wearing any purple clothes contrary to the Roman or Byzantine emperors. It is not the case of the women of the court, in particular the last wife of Charlemagne, Liutgarde, as the author of the poem Karolus Magnus and Leo Papa reports, shortly after 800 [44]. He describes the queen richly dressed in gold, in precious stones and in purple to Paderborn: "Candida purpureis cinguntur tempora vittis/Aurea took off lignat clameidem, capitique byrillus/ 


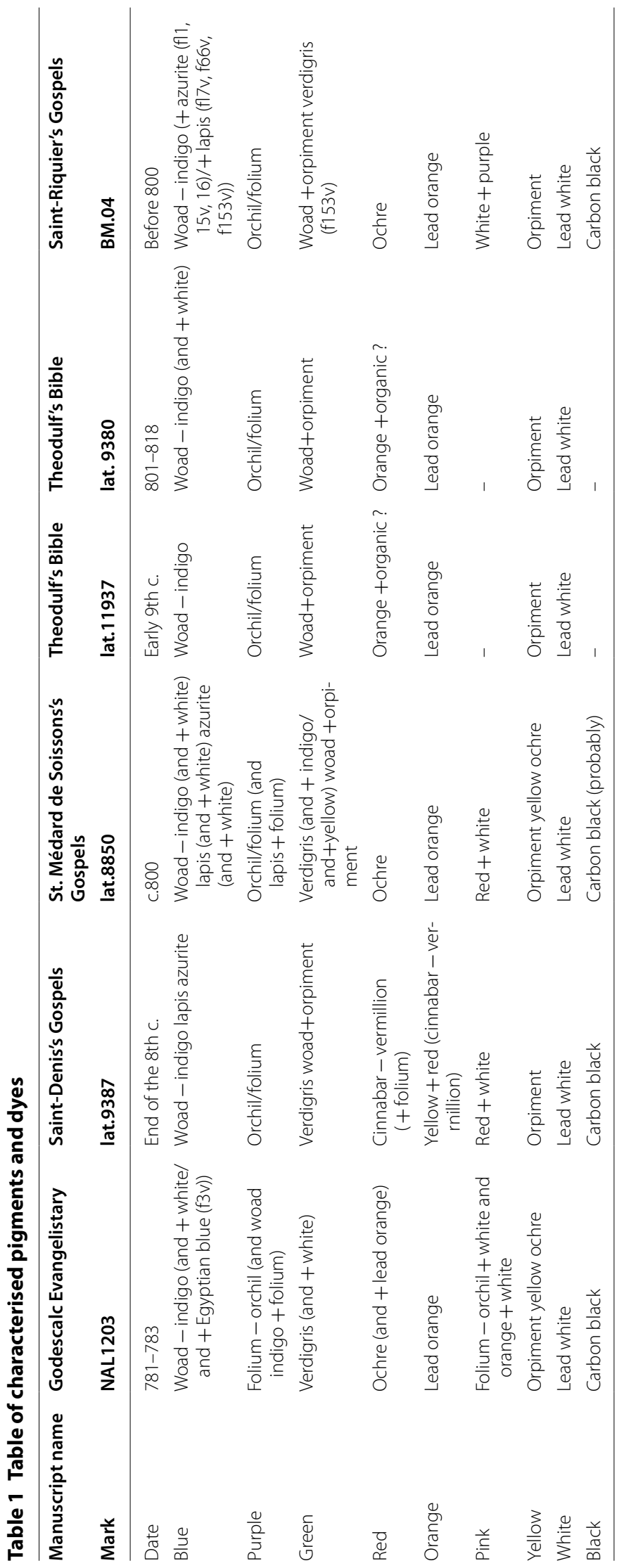




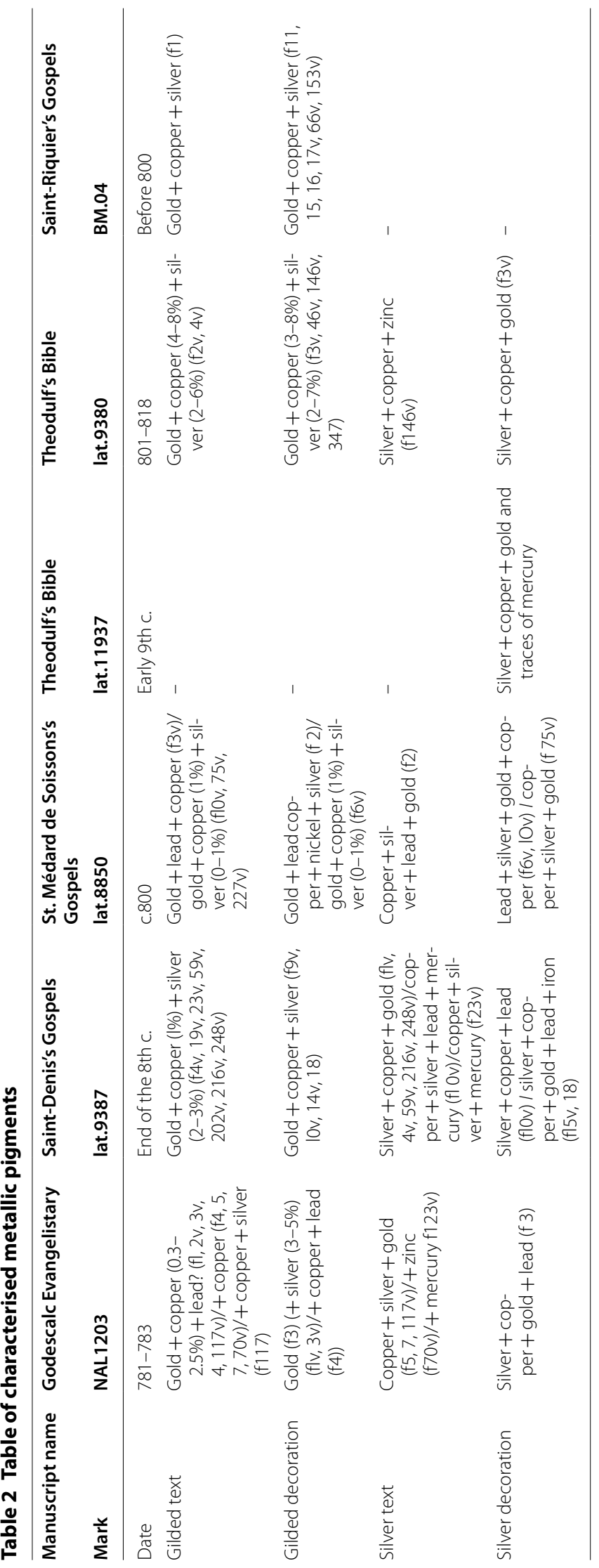




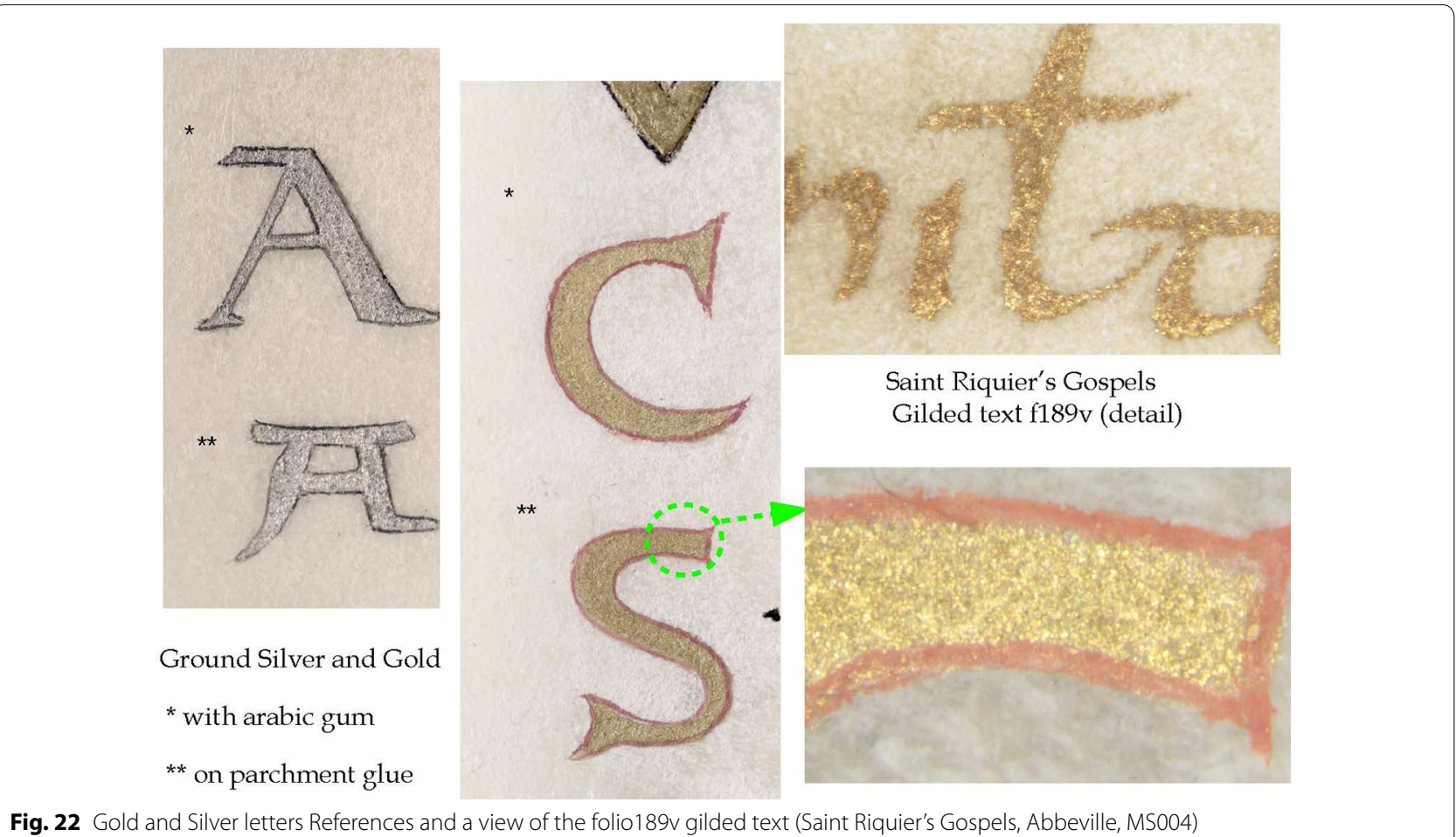

Fig. 22 Gold and Silver letters References and a view of the folio189v gilded text (Saint Riquier's Gospels, Abbeville, MS004)

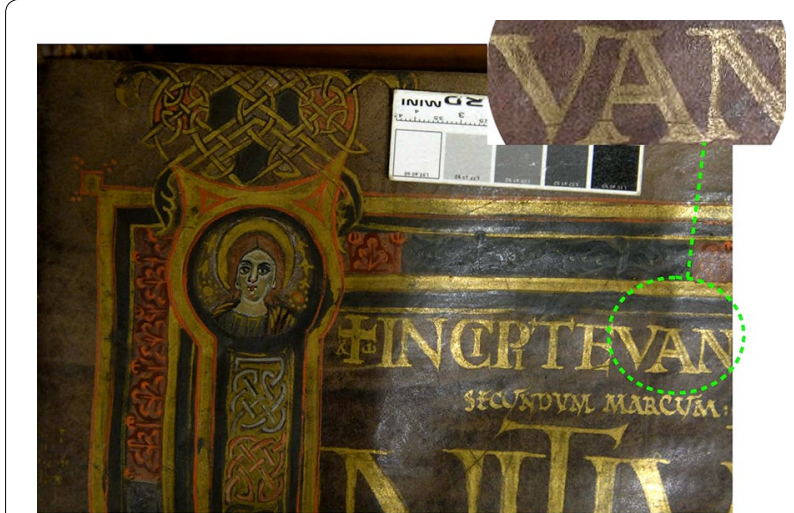

Fig. 23 View of the golden border of the great Initials on folio 67 (Saint Riquier's Gospels, Abbeville, MS004)

Inseritur, radians claro diadema steelworker./Enitet and vestis biscocco purpura bysso./Ornantur variis radiantia stuck lapillis. "Her white temples are surrounded with purple headbands,/a golden thread lines her chlamyde, and her head is set by a beryl, glittering diadem in the brilliant metal./her purple garment, of an invaluable scarlet linen, glitters./diverse stones adorn the neck and make it shine.." After his coronation in the year 800 , he did not

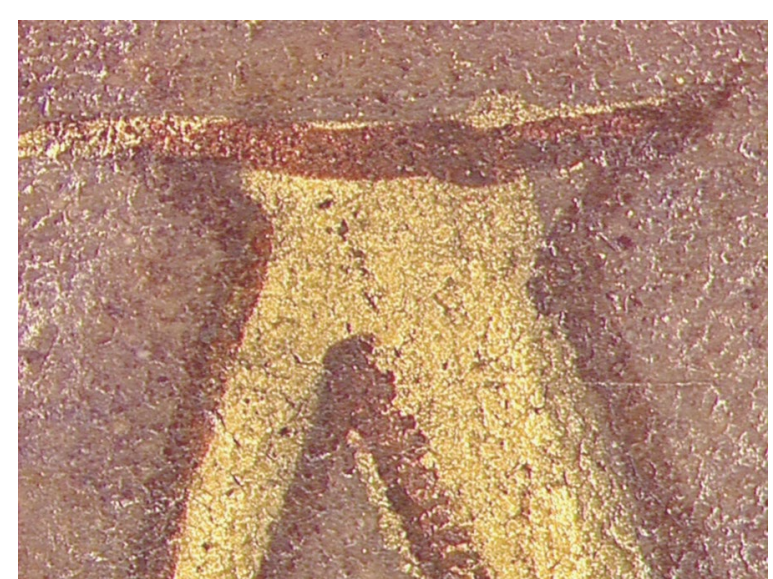

Fig. 24 Purple border of a golden Initial, detail, (Godescalc Evangelistary, folio1, BnF, NAL1203)

establish the imperial privilege concerning the use of this colour. However, the production of purple Gospels has a strong religio-political meaning, as the representation of the Emperor's portrait in biblical books will have under his successors. By the use of the Purple, the colour of blood of the martyrs and the Church, Charlemagne 


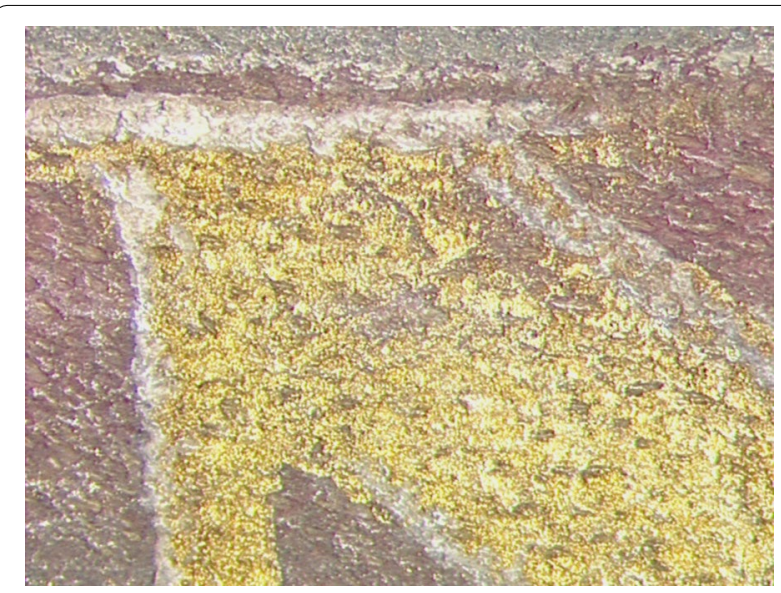

Fig. 25 White border of a golden Initial, detail, (Saint Denis's Gospels, folio18, BnF, latin 9387)

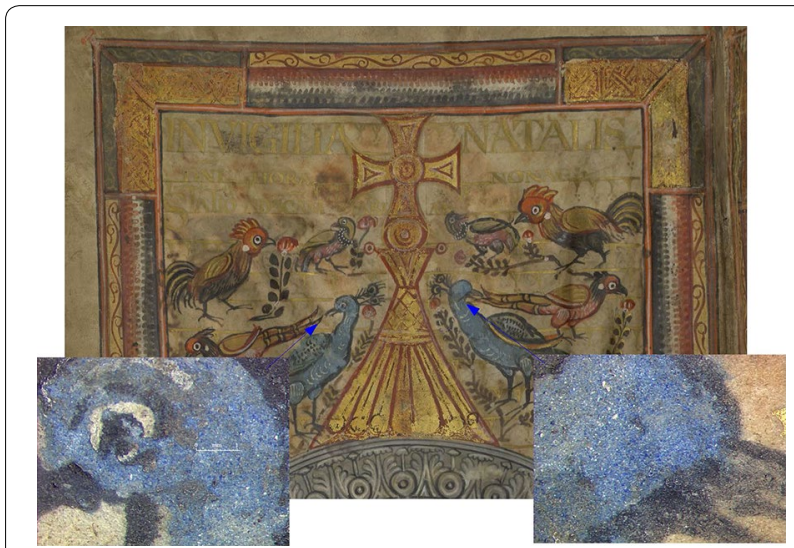

Fig. 26 Egyptian blue on body's and neck's peacoks, detail, (Godescalc Evangelistary, folio3v, BnF, NAL1203

presents himself as a new Constantine, defender and propagator of the Christian faith.

\section{Abbreviation}

BnF: Bibliothèque Nationale de France.

\section{Authors' contributions}

$C D$, PRP, drafted the manuscript, CD provided the historic corpus PRP conducted the experiments and the data analysis. PRP, AMB and NPS performed references dyes and paints on parchment. CD, PRP, AMB, NPS oversaw the whole work. All authors read and approved the final manuscript.

\section{Author details}

1 Bibliothèque national de France, 58 rue de Richelieu, 75002 Paris, France. ${ }^{2}$ CNRS, UMR5060, IRAMAT Centre Ernest-Babelon-Université d'Orléans, Rue de la Ferollerie, 45100 Orléans, France. ${ }^{3} 1$ Rue de la Loire, 41220 Saint Laurent Nouan, France. ${ }^{4}$ Atelier de Siloë, 44 rue Dareau, 75014 Paris, France.

\section{Acknowledgements}

The authors are very grateful to Lise and Sterling, who helped for translation; thank to BnF and Abbeville, Orléans libraries which protect the precious manuscripts; to the Laboratory of Orléans for all support.

\section{Competing interests}

The authors declare that they have no competing interests.

\section{Availability of data and materials}

Most of the data is published in this paper and others are accessible in listed references.

\section{Consent for publication \\ Not applicable.}

\section{Ethics approval and consent to participate}

Not applicable.

\section{Funding}

This study was supported by the CNRS. The authors thank Management and Staff of the BnF, Abbeville and Orléans Libraries.

\section{Publisher's Note}

Springer Nature remains neutral with regard to jurisdictional claims in published maps and institutional affiliations.

Received: 20 October 2017 Accepted: 16 April 2018

Published online: 10 May 2018

\section{References}

1. Lafitte MP, Denoël C. Trésors carolingiens, Livres manuscrits de Charlemagne à Charles le chauve sur les textes liturgiques. Paris: Bibliothèque Nationale de France; 2007. p. 43-7.

2. Crivello F. Les Evangiles de Saint-Denis et l'influence de l'École de la cour de Charlemagne sur les scriptoria de Francie occidentale. In: Caillet JP, Laffitte MP, editors. Les Manuscrits carolingiens. Bibliologia, 27. Turnhout: Brepols; 2009. p. 45-88.

3. Michel RH, McGovern PE. The chemical processing of royal purple dye ancient descriptions as elucidated by modern science. Archeomaterials. 1987:1:135-43.

4. Guineau B. Glossaire des matériaux de la couleur. Turnhout: Brepols; 2005.

5. Cardon D. Le monde des teintures naturelles. Paris: Belin; 1999. p. 421-3 (revised and expanded edition in 2014).

6. Pliny the Elder. Natural History, éd. Emile de Saint-Denis, Paris: les Belles Lettres; 1955, L.9/61; L.9/60; L.22/3; L. 9/82.

7. Pliny the Elder. Natural History, éd. Emile de Saint-Denis, Paris: les Belles Lettres; 1955, L.9/60.

8. Motteran G. Le Sang des Evangiles. Etude systématique des manuscrits tardo-antiques pourprés contenant les Evangiles. Master's thesis EHESS dir. By Ronconi Filippo. Paris; 2012.

9. Malgouyres P. Porphyre: La pierre pourpre des Ptolémées aux Bonaparte. Exhibition catalog: Paris, Louvre Museum, 17nov2003-16fev2004. Paris: Réunion des musées nationaux; 2003.

10. Suetonius. The twelve Caesars. Nero Claudius Caesar, ch. XXXII. Harmondsworth: Penguin; 1957 (revised 2007).

11. Pliny the Elder. Natural History, éd. Emile de Saint-Denis, Paris: les Belles Lettres; 1955, L.22/3.

12. Pliny the Elder. Natural History, éd. Emile de Saint-Denis, Paris: les Belles Lettres; 1955, L. 9/82.

13. von Schlosser J. Schriftquellen zur Geschichte der karolingischen Kunst. Vienna: Olms; 1892.

14. Schramm PE, Mütherich F. Denkmale der deutschen Könige und Kaiser, Ein Beitrag zur Herrschergeschichte von Karl dem Grossen bis Friedrich II., 768-1250. Munich: Prestel Verlag; 1962.

15. Notkerus Balbulus. Gesta Karoli Magni. Monumenta Germaniae Historica, Scriptores rerum germanicarum, Nova Séries, 12, 1/18, Berlin; 1959. p. 22.

16. Ensslin W. Theoderich der Grosse. Munich: Münchner Verlag; 1947. 
17. Bigus M. Codex Argenteus and political ideology in Ostrogothic kingdom. Lychnos. 2011;2:7-27.

18. Crivello F, Denöel C, Orth P. Das Godescalc-Evangelistar: eine Prachthandschrift für Karl den Grossen. Darmstad: Primus; 2011.

19. Laffitte MP. L'évangéliaire de Charlemagne, texte, histoire, reliure. Art de I'enluminure, vol. 20. Dijon: Faton; 2007. p. 4.

20. Crisci E, Eggenberger C, Fuchs R, Oltrogge D. II Salterio purpureo Zentralbibliothek Zürich, RP 1, Segno et Testo 5. Turnhout: Brépols; 2007. p. 31-98.

21. Fuchs R, Oltrogge D. "Gold and Purpur. Zwischen ideal und werkstattpraxis", Signo et Testo 5. Turnhout: Brépols; 2007. p. 82-98.

22. Crivello F. Das Krönungsevangeliar des Heiligen Römischen Reiches. Wien, Kunsthistorisches Museum Weltliche Schatzkammer Inv.-Nr. XIII 18. Interimskommentar zur Faksimile-Ausgabe. Faksimile-Verlag, Munich; 2012. p. $472+208$. ISBN:978-3-577-12943-5.

23. Aceto M, Agostino A, Fenoglio G, Idone A, Crivello F, Griesser M, Kirchweger F, Ulhir K, Roger-Puyo P. Analytical investigations on the Coronation Gospels manuscript. Spectrochim Acta Part A Mol Biomol Spectrosc. 2016;171:213-21.

24. Eveno M, Délit J, Nowik W. La bible de Théodulphe (IXe siècle) de la cathédale du Puy-en-Velay. Identification du colorant des feuillets pourprés et restauration du volume. Tracé. 2003:3:16-24.

25. Guineau B. Le folium des enlumineurs, une couleur aujourd'hui disparue. Ce que nous rapportent les textes sur l'origine et la fabrication de cette couleur, son procédé d'emmagasinage sur un morceau d'étoffe et son emploi dans l'enluminure médéviale. Identification de folium dans les peintures du IXe s., du Xe s. et du début du Xle s. Revue d'archéologie médiévale, XXVI., CNRS éditions; 1997, p. 23-44.

26. Roger P, Denoël C. Regard sur la production artistique de l'abbaye de Fleury. Congrès de la SFFIC Couleurs et Temps. Paris: Institut National du patrimoine; 2006.

27. Roger P. Etude technique sur les décors de manuscrits carolingiens. In: Laffitte MP, Caillet JP, editors. Les manuscrits carolingiens. Bibliologia, vol. 27. Turnhout: Brepols; 2009. p. 203-16.

28. Roger P. Les pigments et la technique picturale des évangiles de St Riquier. Art de l'enluminure. 2013;46:34-63.

29. Gaborit D. Bible de Théodulphe. Bull Monum. 1969;127(2):160-1.

30. Delisle L. Les Bibles de Théodulfe. Paris: Bibliothèque de l'école des chartes; 1879
31. Freeman A. Theodulf of Orleans and the Libri Carolini. Speculum. 1957;32(4):663-705

32. Freeman $A$, Meyvaert $P$, editors. Opus Caroli regis contra synodum (Libri Carolini). Hahnsche Buchhandlung: Hannover; 1998.

33. Flieder F. Mise au point des techniques d'identification des pigments et des liants inclus dans la couche picturale des enluminures de manuscrits. Stud Conserv. 1968;13:49-86.

34. Guineau B. Glossaire des matériaux de la couleur et des termes techniques employés dans les recettes de couleurs anciennes, De Diversis Artibus, Brépols; 2005, p. 317, 530,720.

35. Merrifield M. Medieval and renaissance treatrises on the arts of painting. New york: Dover; 1999.

36. Wallert A. Chrozophora tinctoria Juss. Problems in identifying and illumination colorant. Int J Preserv Libr Arch Mater. 1990;11(3):141-55.

37. Kanold IB. The purple fermentation vat: dyeing or painting parchment with Murex trunculus. Dyes Hist Archaeol. 2005;20:150-4.

38. Hénocque Abbot. History of the abbey and the city of St Riquier, T1. Amiens: Douillot and cie; 1880. p. 174

39. Sarah G, Bompaire M, Mc Cormick M, Rovelli A, Guerrot C. Analyses élémentaires de monnaies de Charlemagne et Louis le Pieux du Cabinet des Médailles: I'ttalie carolingienne et Venise. Revue Numismatique. 2009:6:355-406.

40. Caffaro A. Scrivere in Oro, Ricettari Medievali d'Arte e Artigianato (secoli IX-XI). Naples: Liguori Editore; 2003/De clarea: manuale medievale di tecnica della miniatura, secolo XI. Salerno. Arci Postiglione Editore; 2004

41. Loumyer G. Les traditions techniques de la peinture médiévale, Nogent le Roi: J Laget. 1920. Bruxelles réimpression; 1996.

42. Michel A. Raban Maur, De laudibus Sanctae Crucis, Louanges de la Sainte Croix, traduit du latin, annoté et présenté par Michel Perrin, avec un Prélude par Jean-Marie Lhôte. In: Bulletin de l'Association Guillaume Budé, no. 3, octobre 1989. p. 309-17.

43. Mc Gurk P. The oldest manuscripts of the Latin Bible, in The Early Medieval Bible: its production decoration and use. Cambridge: Richard Gameson; 1994. p. 22-3.

44. Poetae Latini Aevi Karolini, Monumenta Germaniae Historica, 1, Berlin; 1881 , p. 366-84.

\section{Submit your manuscript to a SpringerOpen ${ }^{\circ}$ journal and benefit from:}

- Convenient online submission

- Rigorous peer review

- Open access: articles freely available online

- High visibility within the field

- Retaining the copyright to your article

Submit your next manuscript at $\boldsymbol{\nabla}$ springeropen.com 